\title{
Effects of Topical Application of CHF6467, a Mutated Form of Human Nerve Growth Factor, on Skin Wound Healing in Diabetic Mice ${ }^{\mathrm{S}}$
}

\author{
A. Giuliani, ${ }^{1}$ L. Lorenzini, ${ }^{1}$ V.A. Baldassarro, ${ }^{1}$ M. Pannella, M. Cescatti, M. Fernandez, \\ G. Alastra, A. Flagelli, G. Villetti, B.P. Imbimbo, L. Giardino, and (1)L. Calzà
}

Department of Veterinary Medical Science, University of Bologna, Italy (A.G., L.L., M.F., L.G.); Interdepartmental Center for Industrial Research in Life Sciences and Technologies University of Bologna, Italy (L.L., V.A.B., G.A., A.F, L.G., L.C.); Department of of Pharmacy and Biotechnology, University of Bologna, Italy (L.C.); Fondazione IRET, Ozzano Emilia, Italy (M.P., M.C.); Chiesi Farmaceutici, Parma, Italy (G.V., B.P.I.)

Received May 21, 2020; accepted August 26, 2020

\begin{abstract}
Nerve growth factor (NGF) is the protein responsible for the development and maintenance of sensory skin innervation. Given the role of appropriate innervation in skin healing, NGF has been indicated as a possible prohealing treatment in pathologic conditions characterized by nerve-ending loss, such as chronic ulcers in diabetes; however, its use as a therapeutic agent is limited by its hyperalgesic effect. We tested the effect of topical application of the nonalgogenic NGF derivative hNGFP61S/R100E in two models of skin ulcer induced in $d b d b$ diabetic mice, investigating healing time, skin histology, reinnervation, and angiogenesis using morphologic and molecular approaches. We showed that the topical administration of CHF6467, a recombinant human NGF in which an amino acid substitution (R100E) abolished the hyperalgesic effect usually associated with NGF, accelerated skin repair in experimental wounds (full-excision and pressure-ulcer) induced in diabetic mice (dbdb). CHF6467-induced acceleration of wound healing was accompanied by increased reepithelization, reinnervation, and revascularization as assessed by
\end{abstract}

histology, immunohistochemistry, and image analysis. Bioinformatic analysis of differentially expressed genes and signaling pathways in the wound tissues showed that protein kinase B-mammalian target of rapamycin was the most regulated pathway. In spite of the transdermal absorption leading to measurable, dose-dependent increases in CHF6467 plasma levels, no systemic thermal or local mechanical hyperalgesia was observed in treated mice. When tested in vitro in human cell lines, CHF6467 stimulated keratinocyte and fibroblast proliferation and tube formation by endothelial cells. Collectively, these results support a possible use of CHF6467 as a prohealing agent in skin lesions in diabetes.

\section{SIGNIFICANCE STATEMENT}

Topical application of CHF6467 accelerates reinnervation, neoangiogenesis, and wound healing in diabetic mice in both fullthickness skin-excision and pressure-ulcer models through the protein kinase $\mathrm{B} / \mathrm{mammalian}$ target of rapamycin pathway and does not induce hyperalgesia.

\section{Introduction}

Wound healing is a complex biologic process involving different cell types that interact in a defined spatial and temporal sequence (Rodrigues et al., 2016). When a skin wound does not repair within an established time window, the lesion becomes a "chronic ulcer," a phenomenon usually

The work was supported by Chiesi Farmaceutici, Parma, Italy. The sponsor/ funder provided the CHF6467 and editorial assistance and contributed to the study design.

${ }^{1}$ A.G., L.L., and V.A.B. contributed equally to this work.

https://doi.org/10.1124/jpet.120.000110.

S This article has supplemental material available at jpet.aspetjournals.org. associated with comorbidities, such as diabetes, obesity, cardiovascular diseases, or simply aging (Jaul et al., 2018), and as complication of surgical wounds (Nenna et al., 2019). In patients who are diabetic, the incidence of chronic nonhealing wounds is fairly high, with an estimated $2 \%$ of this population in developed countries suffering from nonhealing injuries, whereas complications cause $90 \%$ of limb amputations (Rodrigues et al., 2016). Moreover, the quality of the repaired skin and the occurrence of wound relapse are still open issues (Martinengo et al., 2019). The problem of chronic skin wounds is further complicated by the worldwide increase in diabetes prevalence, contributing to $9 \%$ of global mortality (Shaw et al., 2010).

ABBREVIATIONS: Akt, protein kinase B; ECM, extracellular matrix; HE, hemotoxylin and eosin; HEK, human primary epidermal keratinocyte; hNGF, human NGF; hrNGF, human recombinant NGF; HRP, horseradish peroxidase; HUVEC, human umbilical vein endothelial cell; I/R, ischemiareperfusion; IR, immunoreactive; Mmp, matrix metalloproteinase; moNGF, mouse recombinant NGF; mTOR, mammalian target of rapamycin; NGF, nerve growth factor; PCR, polymerase chain reaction; PECAM-1, platelet endothelial cell adhesion molecule-1; PGP9.5, protein gene product 9.5; PI3K, phosphoinositide 3-kinase; RT, room temperature; TBST, Tris buffer saline solution containing 1\% Tween 20; Thbs, thrombospondin; trkA, neurotrophic tyrosine kinase receptor A; VEGF, vascular endothelial growth factor. 
Despite the efforts made to establish guidelines for acute and chronic skin wound treatment (Powers et al., 2016; Westby et al., 2017; Blume and Wu, 2018; Everett and Mathioudakis, 2018), only three Food and Drug Administration-approved therapies are available: two skin substitutes and a recombinant human platelet-derived growth factor (PDGF-BB, becaplermin, Regranex). Given that $50 \%$ of diabetic ulcers fail to heal (Lebrun et al., 2010), new solutions are needed to shorten healing time; guarantee healing in severe, nonhealing lesions; and prevent ulcer relapse when possible.

One target for new products is the improvement of endogenous regeneration (Wells and Watt, 2018) through growth factors (Werner and Grose, 2003). Originally described as a "neurotrophic factor" by Rita Levi-Montalcini (LeviMontalcini, 1987), nerve growth factor (NGF) supports a number of physiologic processes in the human body (Levi-Montalcini, 1987). In the peripheral nervous system, the development of thinly myelinated $\mathrm{A} \delta$ or unmyelinated C-fibers, which innervate the skin is an NGF-dependent process (Indo, 2010), and half of the body's nociceptive sensory neurons remain dependent on NGF in adulthood (Snider and McMahon, 1998). Notably, diabetic skin is characterized by reduced epidermal innervation (McCarthy et al., 1995; Kennedy et al., 1996), a factor considered to be one of the main causes of diabetic neuropathy (Ebenezer and Polydefkis, 2014) supporting chronic ulcers (Laverdet et al., 2015).

NGF is now considered a "pleiotropic molecule" (Aloe and Calzà, 2004). Inflammatory and immune cells produce NGF and express NGF high- (trkA) and low- (p75 neurotrophin receptor) affinity receptors, whereas inflammation enhances the synthesis of NGF in various tissues (Calzà et al., 1997) and in fibroblasts, epithelial, endothelial, and immune cells (Prencipe et al., 2014; Gostynska et al., 2020). NGF has been indicated as an angiogenic molecule, which stimulates nitric oxide synthase and vascular endothelial growth factor (VEGF) production (Calzà et al., 2001) and induces a variety of effects on endothelial cells by autocrine and/or paracrine mechanisms (Nico et al., 2008; Gostynska et al., 2020). In the skin microenvironment, NGF appears to be a major player in the communication between sensory neurons and skin cells (Chéret et al., 2013).

A role of endogenous NGF in wound healing has been suggested by in vitro, animal, and human studies (Werner and Grose, 2003; Kawamoto and Matsuda, 2004; Chéret et al., 2013), which have led to the approval of NGF eye drops for the treatment of corneal neurotrophic ulcers (Sacchetti et al., 2020) and have demonstrated the role of NGF as a peripheral pain mediator, particularly in inflammatory pain states (Pezet and McMahon, 2006; Lewin et al., 2014).

To distinguish the positive properties of NGF from its detrimental effects, several trkA-binding agents have been developed (Carleton et al., 2018; Bagal et al., 2019). The rare autosomal recessive neuropathy known as hereditary sensory and autonomic neuropathy type $\mathrm{V}$ is caused by a mutation in the NGF gene (R100W), and patients with hereditary sensory and autonomic neuropathy type $\mathrm{V}$ homozygous display a congenital indifference to painful events with deficits in peripheral nociceptors (Einarsdottir et al., 2004). Similarly, replacement of the arginine residue at position 100 with a glutamic acid residue has been shown to abolish NGFinduced hyperalgesia without affecting trkA receptor affinity
(Cattaneo \& Capsoni 2019). The additional replacement of the proline residue at position 61 of NGF with a serine residue leads to a derivative that is bioanalytically distinguishable from endogenous human NGF (hNGFP61S/R100E, CHF6567) (Severini et al, 2017).

The aim of this study was to test the efficacy of topical CHF6467 in two skin ulcer models in diabetic mice. Healing time, repaired skin histology, reinnervation, and angiogenesis were investigated using morphologic and molecular approaches.

\section{Materials and Methods}

Animals and Group Composition. All animal protocols described herein were carried out according to the European Community Council Directives (2010/63/EU), complied with the Animal Research: Reporting of In Vivo Experiments guidelines and the National Institutes of Health Guide for the Care and Use of Laboratory Animals, and were approved by the Ministry of Health (authorization 391/2017-PR). Ten 11-week-old genetically diabetic C57BL/KsJ-m+/ + Leprdb $(\mathrm{db} / \mathrm{db})$ male mice were included in the experiments (CalcoLecco; Charles River Laboratories). The animals were housed with food pellets and water ad libitum and a dark-light cycle of 12 hours. Glycemia was measured prior to treatment the day after the final treatment and prior to sacrifice in nonfasting animals between 9 and 10 AM (Contour XT; Bayer, Basel, Switzerland).

For skin-excision lesions, the following groups were included $(N=8$ each, according to the power analysis of sample size calculation based on a pilot experiment):

- $\mathrm{db} / \mathrm{db}$, wound + vehicle

- $\mathrm{db} / \mathrm{db}$, wound + CHF6467 $1 \mu \mathrm{g} / \mathrm{cm}^{2}$

- $\mathrm{db} / \mathrm{db}$, wound + CHF6467 $10 \mu \mathrm{g} / \mathrm{cm}^{2}$

- $\mathrm{db} / \mathrm{db}$, wound + CHF6467 $30 \mu \mathrm{g} / \mathrm{cm}^{2}$

- $\mathrm{db} / \mathrm{db}$, wound + moNGF, $10 \mu \mathrm{g} / \mathrm{cm}^{2}$

- $\mathrm{db} / \mathrm{db}$, wound + hNGF, $10 \mu \mathrm{g} / \mathrm{cm}^{2}$

For pressure ulcers, the following groups were included $(N=15$ each, according to the power analysis of sample size calculation based on a pilot experiment):

- $\mathrm{db} / \mathrm{db}$, wound + vehicle

- $\mathrm{db} / \mathrm{db}$, wound + CHF6467 $1 \mu \mathrm{g} / \mathrm{cm}^{2}$

- $\mathrm{db} / \mathrm{db}$, wound + CHF6467 $10 \mu \mathrm{g} / \mathrm{cm}^{2}$

- $\mathrm{db} / \mathrm{db}$, wound + CHF6467 $100 \mu \mathrm{g} / \mathrm{cm}^{2}$

Intact mice were also included for histology and immunohistochemistry experiments. For each model, mice were randomly assigned to the experimental groups after lesion induction.

On the day of sacrifice, mice were deeply anesthetized, and skin samples $(1 \mathrm{~cm} \times 1 \mathrm{~cm})$ were taken from the area of the wound. For the skin-excision study, four samples were collected from each group for immunohistochemistry, and four samples were collected for histology. For the pressure-ulcer study, a 6-mm skin area was taken using an excisional punch (wound area). A 6-mm area of intact skin was collected for an exploratory tumorigenic study.

For the pathway array experiments, six mice from each group were used.

Drugs, Surgery, Wound Dressing, and Monitoring. The following compounds were included in the study: CHF6467, provided by Chiesi (produced by AGC Biologics; Heidelberg, Germany) as well as human $\beta$-NGF, recombinant, Escherichia coli (hrNGF, N-245; Alomone, Jerusalem, Israel) and mouse NGF, recombinant (moNGF 1156-NG; R\&D System). The CHF6467 production process is completely devoid of additives of animal or human origin, and the purification process has incorporated technological advances, including precursor and multimodal chromatography resins. The recombinant NGF protein was expressed in E. coli refolded from inclusion bodies, purified, and proteolytically processed to NGF, as previously 
described (patent PCT/EP2019/060733). The vehicle was a solution of purified water, acetic acid $20 \mathrm{mM}$, and L-methionine $20 \mathrm{mM}$, pH 5.5.

For the skin-excision model, a 6-mm circular full-thickness wound was created by dermal punch biopsy on the midback of the animals, and the wound area was immediately covered with a Tegaderm dressing (3M Health Care; Tegaderm Roll, St.Paul, MN). A 26-gauge needle was used to infuse $50 \mu \mathrm{l}$ of medication through the Tegaderm into the wound bed. Compounds and vehicle were administered daily for a total of 7 days from the time of surgery onward (Fig. 1A) (Landi et al., 2003), and animals were monitored daily for dressing integrity and infection. The Tegaderm was changed weekly in all animals until wound healing was complete. Photographs were taken to monitor the wounds, and the area was measured using Nis-Elements AR 3.2 software (Nikon Corporation, Tokyo).

Pressure ulcers were induced using two magnetic disks of 12-mm diameter and a thickness of $5.0 \mathrm{~mm}$ with an average weight of $2.4 \mathrm{~g}$ and 1000-G magnetic force (Algamagnetic, Italy). A skin fold was gently raised and placed between the two magnets. This procedure left a 1.0-cm skin bridge between the magnets, creating about $50 \mathrm{~mm} \mathrm{Hg}$ compressive pressure between the two plates (Stadler et al., 2004). Three ischemia-reperfusion (I/R) cycles were used, in which a single I/R cycle consisted of a period of 12 hours for the application of the magnets followed by a rest period of 12 hours without magnets. Application of the compounds (60 $\mu \mathrm{l}$ in each ulcer) began after wound curettage (at day 3 after the last I/R cycle) and was continued daily until 50\% closure at the same dosage (day 14), and then it was continued twice a week $(40 \mu \mathrm{l}$ day $17,20 \mu \mathrm{l}$ from day 19) until $100 \%$ closure at the same dosage (Fig. 5A). Treatment of the wound after surgical curettage consisted of removal of the exudate by gentle application of sterile gauze soaked in sterile saline solution. The wounds were dressed with Tegaderm, which was replaced as above. The lesions were monitored via visual inspection by two independent operators to establish day of closure, without Tegaderm removal.

Hyperalgesia. Thermal hyperalgesia was evaluated in freely moving animals by Hargreaves method using the Thermal Plantar Test Instrument (Ugo Basile, Comerio, Varese) on day 0 (before surgery) and day 7 (the day after the final NGF application). The mean-of-four latency to paw-retraction measurements was used for statistical analysis.

Local mechanical hyperalgesia was evaluated using the Electronic Von Frey apparatus (Bioseb, Vitrolles Cedex, France) fitted with an elastic spring tip at the edge of the wound on a gently constricted animal. The mean-of-four measurements were used for the statistical analysis.

Total NGF Plasma Assay. The Human Adipokine Magnetic Bead Panel 2 kit (HADK2MAG-61K; EMD Millipore Corporation, Billerica, MA) was used to quantify the hNGF in the plasma samples using $\times$ MAP technology and a MAGPIX Luminex platform. The assay

A

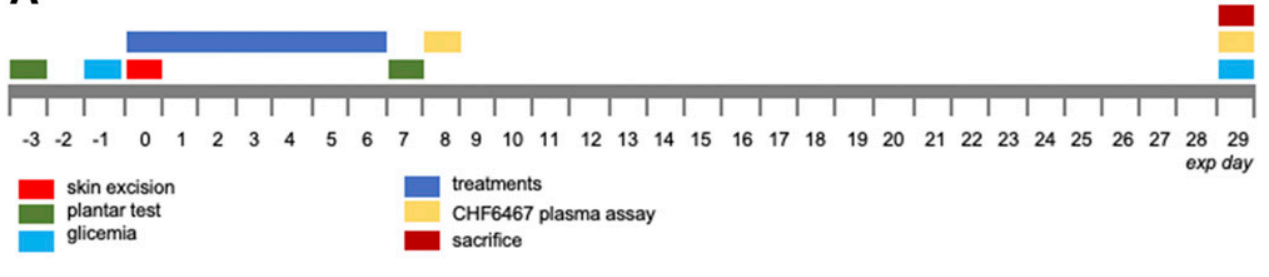

B

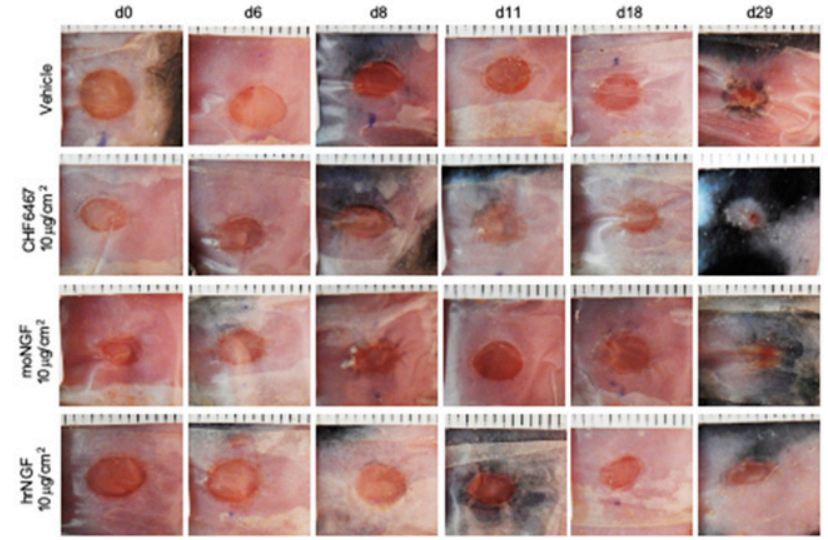

C

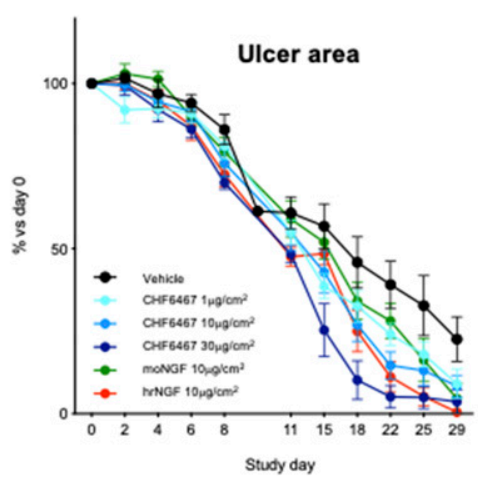

D

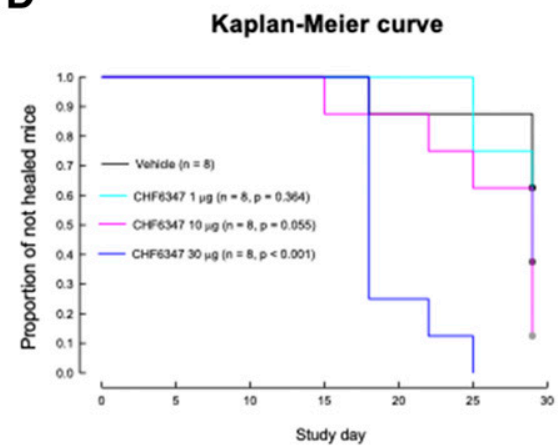

Fig. 1. Full-thickness excision lesion: schedule of the experiment and healing curves; exp day (experimental day). (A) Schedule of the experiment. (B) Representative photos of the ulcers at different postlesion times in vehicle, CHF6467, moNGF, hrNGF, $10 \mu \mathrm{g} / \mathrm{cm}^{2}$-treated $d b d b$ mice. (C) Ulcer areas in the experimental groups, expressed as a percentage of the skin lesion area at day 0 . Statistical analysis: two-way ANOVA indicates a time effect $[\mathrm{F}(50,434)=417.3, P<$ $0.0001]$, a treatment effect $[\mathrm{F}(5434)=$ $21.45, P<0.0001]$, and an interaction $[\mathrm{F}$ $(50,434)=1.638, P=0.0055]$. (D) KaplanMeier curve expressing the nonhealing probability in the experimental groups. 
was performed according to the manufacturer's specifications, with some in-house modifications. In brief, after incubation of the bead population with plasma samples $(25 \mu \mathrm{l})$ overnight at $\mathrm{RT}$, the beads were washed and incubated, initially with detection antibody solution for 1 hour at RT and then with the streptavidinphycoerythrin-conjugated solution for 30 minutes RT. After washing, the beads were resuspended in $100 \mu$ l of Drive fluid and read on the MAGPIX instrument. The data were analyzed using xPONENT 4.2 software, and the results were expressed as picogram per milliliter. We obtained values within the dynamic range of the standard curve (from 10,000 to $0.128 \mathrm{pg} / \mathrm{ml}$ ) for all the samples. Standard curves had a correlation coefficient $\left(\mathrm{R}^{2}\right)$ value $>0.98$. The detection limit of NGF- $\beta$ was $0.3-0.7 \mathrm{pg} / \mathrm{ml}$.

With this kit, a very small amount of mouse NGF- $\beta$ was quantified in the vehicle group because of antibody species crossreactivity. Moreover, since the recombinant mouse NGF- $\beta$ used for treatment is a homodimer of two 120-amino acid polypeptides that shares approximately $90 \%$ amino acid homology with human NGF- $\beta$, NGF was also quantified in moNGF- $\beta$-treated mice.

Immunohistochemistry and Quantitative Analysis. The samples collected for histology were fixed in paraformaldehyde $4 \%(\mathrm{w} / \mathrm{v})$ and picric acid-saturated aqueous solution in Sörensen buffer $0.1 \mathrm{M}$ (pH 7), embedded in paraffin, sectioned at $4 \mu \mathrm{m}$, and stained using hematoxylin and eosin (HE). The samples collected for immunohistochemistry were rapidly removed and fixed as above for 24 hours and then washed for at least 48 hours in $5 \%$ sucrose in $0.1 \mathrm{M}$ phosphate buffer. Cryostat sections (14 $\mu \mathrm{m}$-thick) were incubated overnight at $4^{\circ} \mathrm{C}$ with the primary antibodies: Laminin (Rabbit, 1 : 1000; Sigma), PGP9.5 (Rabbit, 1:2000; Boheringer), and PECAM-1 (Goat, 1:150; R\&D systems). After being rinsed in PBS for 20 minutes, the sections were incubated with the secondary antisera conjugated with Rhodamine Red-X-conjugated - affinity-pure Donkey anti-Rabbit IgG (Jackson Immunoresearch) or secondary DyLight 488 Donkey anti-Goat IgG (Thermo Fisher Scientific) diluted in 0.3\% Triton/PBS. The sections were then rinsed in PBS mounted in glycerol containing 1,4-phenylendiamine $(0.1 \mathrm{~g} / \mathrm{l})$.

Immunofluorescence images were captured using a Nikon Eclipse E600 microscope equipped with the Q Imaging Retiga-2000RV digital CCD camera (Q Imaging, Surrey, BC, Canada) and a $z$-axis motorized stage. Analyses were performed using the Nis-Elements AR 3.2 software by applying the same procedure to all images under comparison. Briefly, five z-stakes every $2 \mu \mathrm{m}$ were collected from each image $(300 \times 500 \mu \mathrm{m})$, and the maximum intensity projection was used to calculate the immunoreactive area. For all morphologic analyses, five images and two levels/animal sampled in the epidermal papillae at the center of the repaired ulcer were analyzed in each animal. All analyses were performed blindly. The immunoreactive area was calculated as area per fraction (percentage of laminin/ PECAM-1 and PGP9.5 over $400 \times 300 \mu \mathrm{m}$ area). The measurement of repaired epidermal thickness was performed on histologic sections ( $4 \mu \mathrm{m}$-thick, HE) in the same area. The mean value of five measurements/section and two sections for animal was used for the statistical analysis. In preparing the figures, the immunofluorescence images were occasionally contrasted. Whenever this was the case, the same procedure was applied to all images under comparison.

Reverse-Transcription Polymerase Chain Reaction and STRING Analysis. Samples for RT2 Profiler PCR arrays (Qiagen) were collected from the full-thickness skin-excision experiment at the core of the lesion (6-mm diameter), and RNA was extracted from all animals (six animals/group) and then quantified and pooled.

Pooled RNAs were retrotranscribed using the RT2 First Strand Synthesis Kit (Qiagen). Each pooled group was tested using a single PCR array, using the CFX96 real time PCR instrument (Bio-Rad).

Qiagen mouse angiogenesis, extracellular matrix and adhesion protein, neurotrophins, and growth factors were used to profile the expression of 250 genes. The possible tumorigenesis effect was also investigated using the dedicated array. The relative gene expression was calculated using the $2^{-(\Delta \Delta \mathrm{Cq})}$ comparative method.
The dedicated Qiagen online data analysis software for the relative quantification of gene expression was used to perform the analysis and generate the graphs. The differentially expressed genes identified were then plotted in the STRING network analysis software (v.10; http://string-db.org/) to analyze the functional interactions between their biologic functions.

Cell Culture, Immunocytochemistry, and Image Analysis. To test the CHF6467 activity in skin cell lines, adult human primary epidermal keratinocytes (HEKs) (American Type Culture Collection PCS-200-011), human skin fibroblast cell lines (BJ, American Type Culture Collection CRL-2522), and human umbilical vein endothelial cells (HUVECs) (umbilical vein endothelial cells pooled from multiple isolates, Invitrogen C-015-5C; Thermo Fisher Scientific, Waltham, MA) were used and cultured according to the respective conventional protocols (Gostynska et al. 2020).

For the cell proliferation assay, cells were seeded in 96-well plates (BJ, $3.5 \times 10^{3}$ cells/well, FBS $2 \%$; HEK, $2 \times 10^{3}$ cells/well, no FBS) and treated with CHF6467 at $0,50,100$, or $200 \mathrm{ng} / \mathrm{ml}$, with the medium being changed every second day. Every 2 days, for 8 or 10 total days for HEK and BJ cells respectively, cells were detached by trypsinization and counted using a Bürker chamber (three wells/time point, two counts/well).

HUVECs were used for the tube-formation assay. Cells were seeded overnight at $9 \times 10^{4}$ cells/well in 24 -well plates in culture medium containing $0,50,100$, or $200 \mathrm{ng} / \mathrm{ml}$ of CHF6467. The next day, the cells were detached by Trypsin/EDTA and seeded on Geltrex LDEV-free matrix (Thermo Fisher Scientific) in culture medium containing the same concentration of CHF6467. Tube-formation analysis was performed after 8 hours. Cells were fixed, washed, incubated with blocking solution for 1 hour, and then overnight at $4^{\circ} \mathrm{C}$ with primary antibody (rabbit actin, 1:200; Santa Cruz). After two washes in PBS, cells were incubated with secondary antibody (Donkey anti-rabbit Alexa Fluor 488, 1:500; Molecular Probes) and Hoechst nuclear staining at $37^{\circ} \mathrm{C}$ for 30 minutes and finally washed twice in PBS. Cultures were analyzed using the cell-based High Content Screening technology (CellInsight CX5 HCS Platform; Thermo Scientific). The angiogenesis algorithm of the CellInsight software permits detection of all cells present in the well by identification of the nuclei (Hoechst staining), and each cell body by structural protein staining (actin). The angiogenesis index is automatically calculated as follows: angiogenesis index $=(1000 \times$ total area of connected tubes $) /$ total image area $=$ $(\%$ of the image area covered by connected tubes $) \times 10$.

HUVEC and BJ cells cultured in high-glucose conditions and treated with CHF6467 $200 \mathrm{ng} / \mathrm{ml}$ for 48 hours were used for Western blot analysis.

Western Blot. Western blot analysis was performed to quantify the protein kinase B (Akt) protein expression in cell cultures and skin. For skin tissue samples, the analysis was performed on the same samples used for reverse-transcription PCR and STRING analysis and from intact skin. The skin tissue was homogenized in radioimmunoprecipitation assay buffer and protease inhibitor (1x cocktail inhibitor Sigma, $1 \mathrm{mM}$ phenylmethylsulfonyl fluoride, $10 \mathrm{mM}$ sodium fluoride, $1 \mathrm{mM}$ sodium orthovanadate) with a homogenization ratio 1 : 8 (mg: $\mu \mathrm{l}$ ) and centrifuged at $12,000 \mathrm{~g}$ for 20 minutes at $4^{\circ} \mathrm{C}$. Cells were detached from the culture plates and centrifuged, and the pellet was resuspended in radioimmunoprecipitation assay buffer and protease inhibitor. Total protein concentration was estimated using a standard colorimetric method. For each experiment, the same quantity of proteins was loaded (tissues $25 \mu \mathrm{g}$; HUVECs, $15 \mu \mathrm{g}$; BJ, $0.5 \mu \mathrm{g}$ ), and the marker protein (Precision Plus Protein Standards; Bio-Rad) was added.

A solution of Leammli/ $\beta$-mercaptoethanol was added to each sample, and after heating treatment $\left(100^{\circ} \mathrm{C}, 5\right.$ minutes $)$, the proteins were resolved in 4\%-20\% Mini-PROTEAN TGX Stain-Free Gels (BioRad) and transferred to Amersham Protran $0.45 \mu \mathrm{m}$ Nitrocellulose Blotting Membrane (Bio-Rad). After blocking in Tris buffer saline solution containing $1 \%$ Tween 20 (TBST) and $2.5 \%$ bovine serum albumin, membranes were incubated with the primary antibody 
(rabbit pan-Akt, 1:1000; Cell Signaling, Leiden, The Netherlands; mouse $\beta$-actin, 1:150; Santa Cruz Biotechnology -Dallas, TX) overnight at $4^{\circ} \mathrm{C}$. After washing three times in TBST, the membranes were incubated with HRP-conjugated secondary antibodies (swine anti-rabbit, 1:5000; Dako; swine anti-mouse, 1:5000; Dako) and HRP-conjugated protein for marker visualization (Precision Protein SrepTactin HRP-conjugate, 1:10,000; Bio-Rad) for 1 hour at RT. The membranes were then washed three times with TBST. The immunoreactive signal was detected by incubating the membranes with Clarity Western ECL Substrate (Bio-Rad) for 5 minutes at RT in darkness and using the Bio-Rad Chemi DOC MP imaging systems.

Western blot signals were measured by densitometry using Image $J$ (Fiji) software. The Akt signals were normalized on $\beta$-actin in all the analyzed samples. Akt quantification was further normalized on intact skin values to obtain the variation index (intact skin $=1$ ). For cell-culture samples, normalized Akt values were used for the analysis. Western blot signals were measured by densitometry using ImageJ (Fiji) software.

Statistical Analysis. Data are expressed as mean \pm S.E.M. Statistical comparison of the rate of skin ulcer healing over time between treatment groups was performed with the log-rank test that compares the hazard functions of the different groups at each observed event time (Kaplan-Meier analysis). The Holm-Sidak test was used for multiple comparisons versus a control group (vehicle) (SigmaPlot 11; Systat Software Inc., San Jose, CA). Histologic and immunohistochemical results are reported as mean \pm S.E.M. Prism software (GraphPad Software, San Diego, CA) was used for the statistical analyses of this data and for graph generation. The Student's $t$ test or one-way ANOVA were used to analyze the data. Results were considered significant when the probability of their occurrence as a result of chance alone was less than $5 \%(P<0.05)$.

\section{Results}

\section{PC12 In Vitro Assay}

CHF6467 biologic activity in PC12 cells was compared with that of moNGF and hrNGF using the neurite elongation test (Radio et al., 2008) performed by HCS measuring the average neurite length per cell, total neurite length per cell, and the percentage of cells showing a neurite equal to or longer than the cell body length. Results are presented in Supplemental Fig. 1. Initially, all NGF treatments were compared with the vehicle group and, from this analysis, only the most effective concentration for each NGF treatment was selected for further analysis (Supplemental Fig. 2). Compared with the vehicletreated group, all effective NGF treatment doses showed a significantly higher mean-neurite length (moNGF, $P=$ 0.0394; hrNGF, $P=0.0196$; CHF6467, $P=0.0033$ ) and mean total-neurite length (moNGF, $P=0.0338$; hrNGF, $P=0.0006$; CHF6467, $P=0.0211$ ). Only CHF6467 was found to significantly increase the percentage of cells showing long neurites $(P=0.0367)$ compared with the vehicle.

\section{Animal Monitoring}

Animals were monitored for glycemia levels and body weight (Tables 1 and 2). All diabetic mice showed very high blood-glucose levels. No differences between the treatment groups were observed at the different times, either in the fullthickness excision or pressure-ulcer model.

\section{Full-Thickness Excision Skin Ulcer}

Wound Healing. The study schedule is shown in Fig. 1A. Pictures of the wounds from representative mice from the vehicle, CHF6467, moNGF, and hrNGF $10 \mu \mathrm{g} / \mathrm{cm}^{2}$ groups are shown in Fig. 1B. The time course of mean percentage reduction in ulcer area compared with baseline is given in Fig. 1C and shows that all NGF treatments significantly (twoway ANOVA, $P<0.0001$ ) accelerated ulcer healing compared with vehicle (post hoc test vs. vehicle: CHF6467 $1 \mu \mathrm{g} / \mathrm{cm}^{2} P<$ 0.0001; CHF6467 $10 \mu \mathrm{g} / \mathrm{cm}^{2} P<0.0001$; CHF6467 $30 \mu \mathrm{g} / \mathrm{cm}^{2}$ $P<0.0001 ;$ moNGF $10 \mu \mathrm{g} / \mathrm{cm}^{2} P=0.0001 ; \mathrm{hrNGF} 10 \mu \mathrm{g} / \mathrm{cm}^{2}$ $P<0.0001$ ). The day of closure in individual mice is given in Supplemental Table 1. At day 29, complete healing was observed in all animals treated with hrNGF $10 \mu \mathrm{g} / \mathrm{cm}^{2}$ or CHF6467 $30 \mu \mathrm{g} / \mathrm{cm}^{2}$. Figure 1D shows the proportion of animals not completely healed over time, with moNGF, hrNGF, and CHF6467 at $30 \mu \mathrm{g} / \mathrm{cm}^{2}$ significantly accelerating the healing process compared with the vehicle.

Pain Threshold. Thermal hyperalgesia was evaluated before skin-lesion induction (day 0) and after the final NGF application (day 7). Results are shown in Fig. 2A. A significant reduction in pain threshold was observed in hrNGF-treated animals. No differences were observed in the other groups.

Total NGF Plasma Levels. Blood was collected 24 hours after the final application of NGF and at sacrifice (see Fig. 1A). Results are shown in Fig. 2B. The kit used to quantify NGF includes a capture monoclonal antibody that recognizes the epitope Ala 46-Asn 62; thus, we quantified the total NGF (i.e., mouse endogenous NGF, since human antibody crossreacts with mouse $\mathrm{NGF}$ ) and the $\mathrm{CHF} 6467$ present in the plasma of the treated animals.

A dose-dependent, transient increase in total NGF plasma level was observed in CHF6467-treated mice, reaching an average value of $350 \mathrm{pg} / \mathrm{ml}$ at day 7 . An increase in total NGF plasma levels was also observed in the moNGF-treated group. This was not surprising, since the recombinant mouse NGF- $\beta$ used for treatments shares approximately $90 \%$ homology with human NGF- $\beta$ at amino acid level (Ullrich et al., 1983). This increase is reversible, as indicated by the low levels of total NGF at sacrifice $(12.80 \pm 3.3 \mathrm{pg} / \mathrm{ml})$. Very low levels of endogenous NGF- $\beta$ were detected in the vehicle-treated mice $(11.0 \pm 1.2 \mathrm{pg} / \mathrm{ml})$, due to human antibody crossreactivity with the mouse protein.

TABLE 1

Body wt. and glycemia of animals included in the full-thickness excision study

\begin{tabular}{|c|c|c|c|c|}
\hline Groups, $N=8$ & Body Wt., Day $-1, \mathrm{~g}$ & Body Wt., Day 26, g & Glycemia, Day $-1, \mathrm{~g} / \mathrm{ml}$ & Glycemia, Day $26, \mathrm{~g} / \mathrm{ml}$ \\
\hline Intact & $42.4 \pm 1.7$ & $43.1 \pm 1.5$ & $434 \pm 33$ & $562 \pm 29$ \\
\hline Vehicle & $38.9 \pm 0.4$ & $36.5 \pm 1.3$ & $406 \pm 35$ & $552 \pm 30$ \\
\hline $\mathrm{CHF} 6467,1 \mu \mathrm{g} / \mathrm{cm}^{2}$ & $40.3 \pm 1.4$ & $38.9 \pm 1.2$ & $398 \pm 37$ & $512 \pm 45$ \\
\hline $\mathrm{CHF} 6467,10 \mu \mathrm{g} / \mathrm{cm}^{2}$ & $39.8 \pm 1.2$ & $35.8 \pm 2.3$ & $482 \pm 27$ & $585 \pm 17$ \\
\hline $\mathrm{CHF} 6467,30 \mu \mathrm{g} / \mathrm{cm}^{2}$ & $38.9 \pm 1.6$ & $37.9 \pm 1.6$ & $360 \pm 64$ & $578 \pm 14$ \\
\hline moNGF, $10 \mu \mathrm{g} / \mathrm{cm}^{2}$ & $38.4 \pm 1.7$ & $38.9 \pm 1.6$ & $391 \pm 36$ & $471 \pm 45$ \\
\hline $\mathrm{hNGF}, 10 \mu \mathrm{g} / \mathrm{cm}^{2}$ & $39.1 \pm 8.9$ & $35.4 \pm 1,8$ & $404 \pm 60$ & $573 \pm 17$ \\
\hline
\end{tabular}


TABLE 2

Body wt. and glycemia of animals included in the pressure-ulcer study

\begin{tabular}{|c|c|c|c|c|}
\hline Groups & Body Wt., Day $-1, \mathrm{~g}$ & Body Wt., Day 26, g & Glycemia, Day $-1, \mathrm{~g} / \mathrm{ml}$ & Glycemia, Day $26, \mathrm{~g} / \mathrm{ml}$ \\
\hline Vehicle, $N=15$ & $38.5 \pm 1.1$ & $35.1 \pm 1.3$ & $339 \pm 31$ & $553 \pm 19$ \\
\hline CHF $6467,1 \mathrm{mg} / \mathrm{cm}^{2}, N=18$ & $39.0 \pm 0.7$ & $37.3 \pm 1.0$ & $361 \pm 29$ & $575 \pm 11$ \\
\hline $\mathrm{CHF} 6467,10 \mathrm{mg} / \mathrm{cm}^{2}, N=18$ & $40.6 \pm 0.9$ & $37.3 \pm 1.0$ & $330 \pm 24$ & $527 \pm 32$ \\
\hline $\mathrm{CHF} 6467,100 \mathrm{mg} / \mathrm{cm}^{2}, N=12$ & $39.4 \pm 1.1$ & $37.0 \pm 1.2$ & $364 \pm 41$ & $518 \pm 42$ \\
\hline
\end{tabular}

Histology and Immunohistochemistry. The entire area of the skin ulcer, including a 5-mm margin of intact skin, was excised, embedded in paraffin, and serially sectioned from the border to the centrum. The sections were then stained (HE), and representative low-power images taken at the different levels of the wound are shown in Fig. 3A (border of the lesion) and Fig. 3D (core of the lesion). High-power micrographs show the re-epithelization process at the wound border (Fig. 3B), where the epidermis migrating tongue and the extensive granulation tissue in the derma below the epidermal layer characterized by inflammation, cell proliferation, matrix deposition, and angiogenesis are evident (Fig. 3E). Re-epithelization has been evaluated by measuring the epidermal layer thickness in the central area of the repaired wound. Nonhealing wounds, as monitored in Supplemental Table 1, were excluded from the analysis. Representative images from intact vehicle- and CHF6467 $30 \mu \mathrm{g} / \mathrm{cm}^{2}$-treated mice are presented in Fig. 3, F-H, respectively, and the results are shown in Fig. 3I. CHF6467 induced a dose-dependent thickening of the epidermal layer, and a comparable effect was observed after treatment with matching doses of both moNGF and hrNGF. In treated mice, the basal layer of the epidermis was characterized by hypercellularity of the basal and spinous layers, possibly reflecting cell proliferation. Moreover, the dermis was also thicker and strongly stained, suggesting a higher extracellular matrix deposition, and showed the presence of skin annexes (glands and hair follicles).

Skin reinnervation was analyzed by immunostaining for the protein PGP9.5. The anatomy of the skin innervation is presented in Fig. 3C, in which PGP9.5-IR fibers in the intact mouse skin can be seen in the subcutaneous, deep cutaneous, and subepidermal fibers. Radial fibers can be seen between the deep-subcutaneous and subependymal plexus, whereas the subepidermal plexus supplies the free epidermal nerve endings to the epidermis.
A

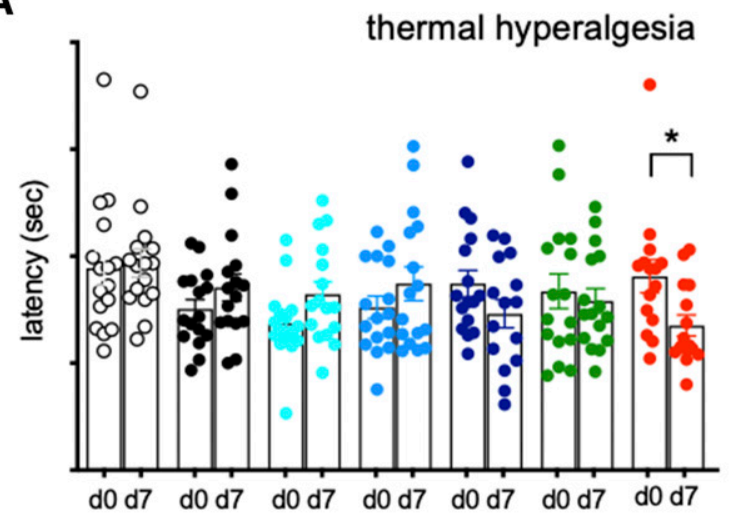

Total NGF plasma levels

B

Day 8

Day 28
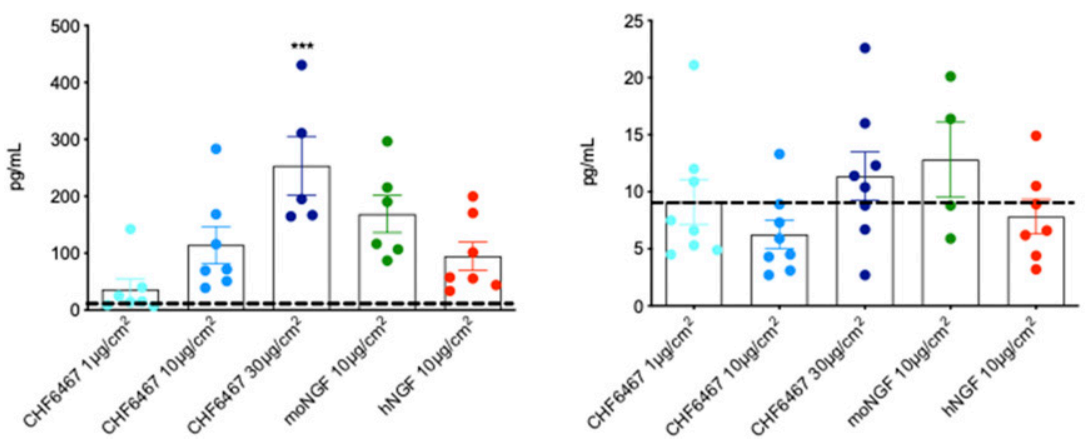

Fig. 2. Pain threshold and NGF plasma levels in fullthickness excision lesion. (A) Thermal hyperalgesia measured before the first topical treatment (day 0) and immediately after the final application (day 7) in all experimental groups. Statistical analysis: Student's $t$ test, ${ }^{*} P<0.05$. (B) Total NGF plasma level 2 hours (day 7) and 21 days (day 28) after the last topical NGF application. The horizontal lines refer to NGF plasma levels in vehicle-treated mice. Statistical analysis: oneway ANOVA and Dunnett's post hoc test, ${ }^{* * *} P<0.001$. 

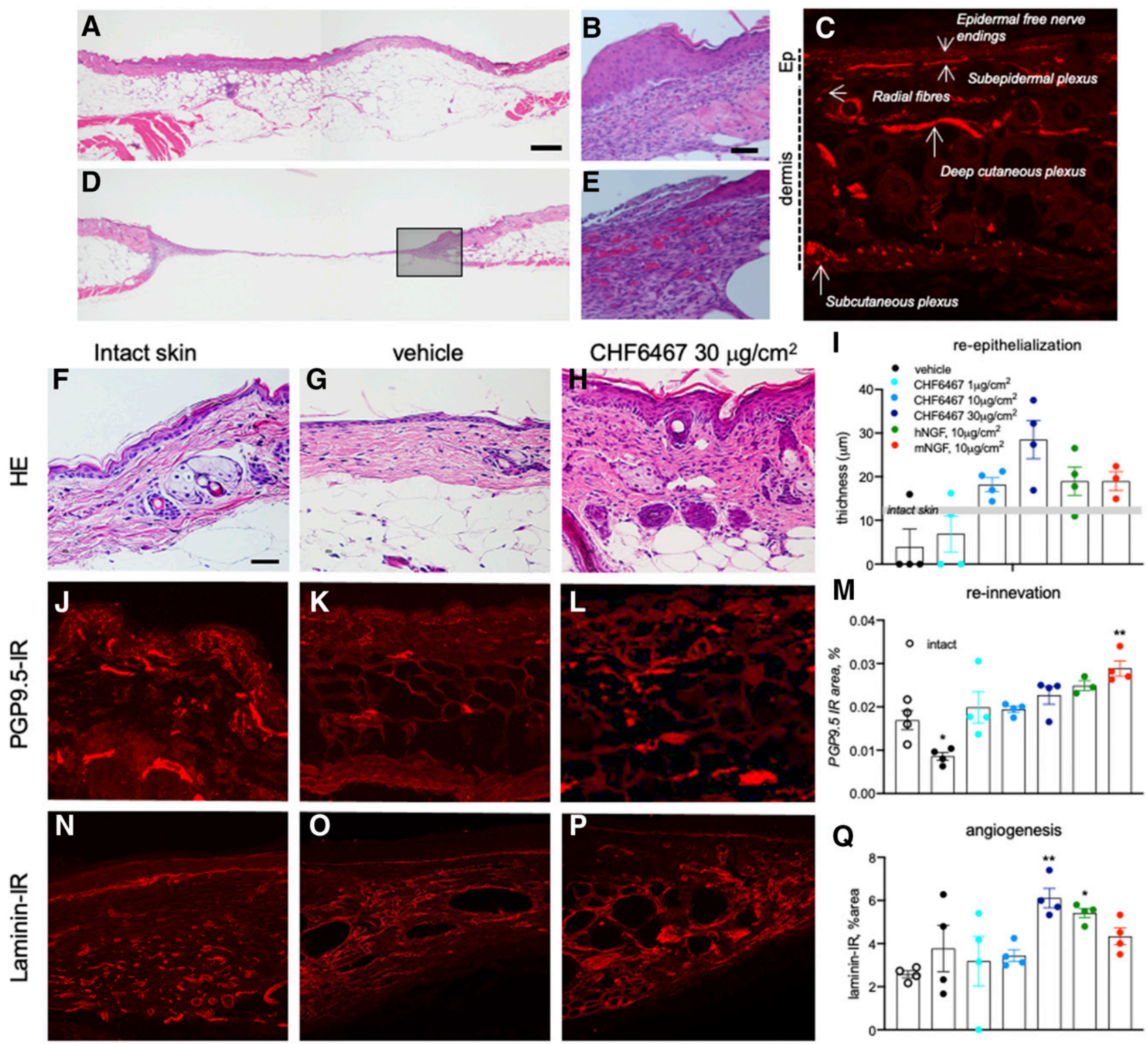

Fig. 3. Histologic and immunohistochemical analysis of the repaired skin in the full-thickness excision model. (A and D) HE staining of the skin biopsy at experimental day 8, tangential to the lesion (A) and at the lesion equator. (B and D) HE staining showing the epithelial cell migration at the lesion border (epidermis migrating tongue) and (E) the underlying extensive granulation and angiogenesis. (C) PGP-9.5 immunostaining in intact skin, illustrating the skin innervation anatomy; Ep (epidermis) (F-I) Representative HE-stained section of the repaired skin in intact (F), vehicle-treated (G), and CHF6467 $30 \mu \mathrm{g} / \mathrm{cm}^{2}$-treated $d b d b$ mice; mNGF (mouse NGF) (H) and morphometric evaluation of epidermal thickness [(I), gray horizontal bar corresponds to intact]. (J-M) Representative micrographs of PGP9.5-IR fibers in repaired skin in intact (J), vehicle-treated (K), and CHF6467 $30 \mu \mathrm{g} /$ $\mathrm{cm}^{2}$-treated $d b d b$ mice $(\mathrm{L})$ and morphometric evaluation of PGP9.5-positive percentage area [(M), white empty circle corresponds to intact]. (N-Q) Representative micrographs of laminin-IR in repaired skin in intact $(\mathrm{N})$, vehicle-treated $(\mathrm{O})$, and CHF6467 $30 \mu \mathrm{g} / \mathrm{cm}^{2}-$ treated $d b d b \mathrm{mice}(\mathrm{P})$ and morphometric evaluation of laminin-positive percentage area [(Q), white empty circle corresponds to intact]. Statistical analysis: one-way ANOVA and Dunnett's post hoc test, ${ }^{*} P<0.05$; ${ }^{*} P<0.01$; $* * * P<0.0001$. Scale bars, (A and D) $500 \mu \mathrm{m}$; (B and E) $50 \mu \mathrm{m}$; (C and F-P) $100 \mu \mathrm{m}$.

Figure 3, J-L illustrates PGP9.5-IR at sacrifice in intact, vehicle-treated, and CHF6467 $30 \mu \mathrm{g} / \mathrm{cm}^{2}$-treated mice, respectively. Results from the morphometric analysis are presented as an immunoreactive percentage area in Fig. 3M. No differences in skin innervation were present between the intact animals, CHF6467 (all dosages), and moNGF groups, and there is no evidence of innervation restoration in vehicle-treated mice. On the contrary, a hyperinnervation is observed using hrNGF.

The effect of topical NGF application on angiogenesis was estimated using laminin as basal membrane marker, thus marking the outer endothelial cell membrane. Representative images are given in Fig. 3, N-P, and the results are shown in Fig. 3Q. CHF6467 $30 \mu \mathrm{g} / \mathrm{cm}^{2}$ induces a significant increase in laminin-IR, as hrNGF, possibly reflecting angiogenesis in progress.

Transcriptome Analysis and Validation. The aim of this experiment was to explore molecular mechanisms supporting the positive effect of CHF6467 on wound healing in diabetic mice, focusing on inflammation, extracellular matrix deposition, innervation, and angiogenesis. For this purpose, an exploratory strategy was used to map mRNA alterations of 252 key genes involved in angiogenesis, ECM, and growth factors in the wound at $50 \%$ of the repair process (see Supplemental Table 3, for the full list). According to the data 
analysis software, the thrombospondin (Thbs) 1 gene was used as the housekeeping gene. The results for angiogenesis (Fig. 4A), extracellular matrix (Fig. 4B), and growth factor (Fig. 4C) genes are presented in Fig. 4 as a scatter plot analysis. Compared with vehicle-treated mice, the CHF6467 $30 \mu \mathrm{g} / \mathrm{cm}^{2}$ treatment downregulated several genes, including Akt1, Ccl2 (chemokine (C-C motif) ligand 2), Ctgf (connective tissue growth factor), Hif1a (hypoxia-inducible factor 1- $\alpha$ ), Mmp14 (matrix metalloproteinase 14), Thbs2, Tnc (Tenascin C), and upregulated Mmp9.

We then analyzed the array data by STRING software analysis for pathway discovery, considering all the differentially expressed genes identified (web-software STRING 10 and Gene Ontology data bases) to predict protein-protein interactions. We adopted stringent inclusion criteria by including genes whose expression changes were greater than the selected boundary $(\geq 3)$. Analysis criteria were also stringent: confidence $=0.9$ (highest, Kyoto Encyclopedia of Genes and Genomes data base); first shell. The results are shown in Fig. 4D, indicating a strong cluster around AktmTOR, which also includes Hif1a (Hypoxia-inducible factor 1-alpha) and Hsp90 (Heat shock protein 90).

To confirm the Akt mRNA downregulation by the CHF6467 compared with vehicle-treated mice, we quantified the Akt protein in the same samples. Values were normalized on the intact skin of the same animals. Western blot analysis confirmed that CHF6467 treatment blocked the ulcermediated increase of Akt (Student's $t$ test, $P=0.0049$, Fig. 4, E and F).

\section{Pressure Ulcer}

Wound Healing. The schedule of the experiment is presented in Fig. 5A. Representative images from the experimental groups are shown in Fig. 5B. "Day of closure" was established based on visual inspection and photo analysis by two independent operators (see Supplemental Table 2 for individual data). The clinical diagnosis of "nonhealing wound" was confirmed by histologic analysis of the specimens.
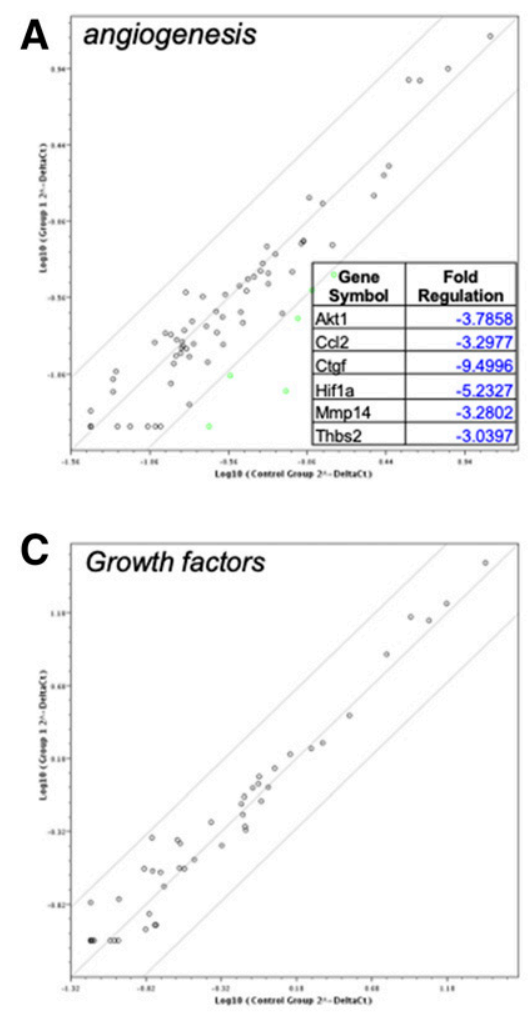

E

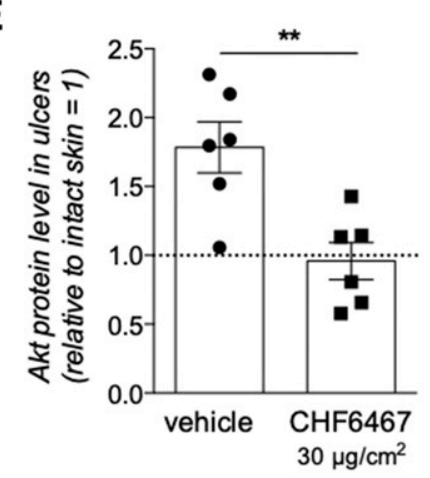

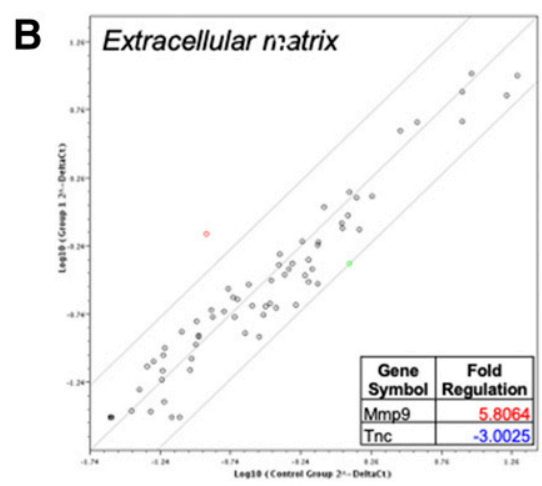

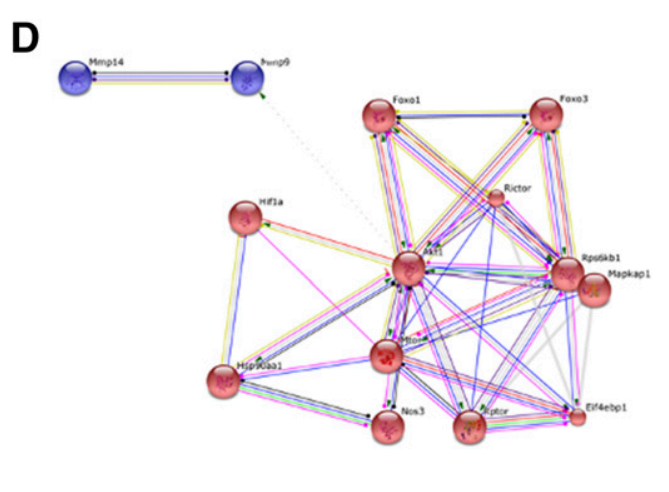

$\mathbf{F}$

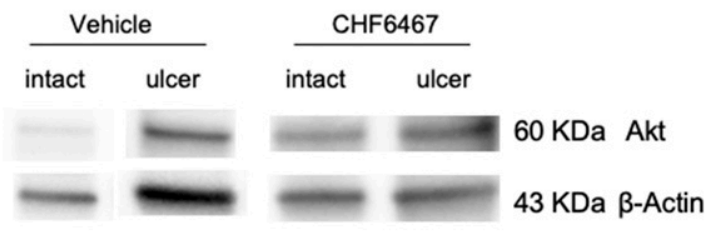

Fig. 4. RT2 Profiler PCR arrays analysis. (A-C) Scatter plot representation of gene expression analysis of RT2 Profiler PCR arrays for specific pathways: angiogenesis (A), extracellular matrix and adhesion molecules (B), and neurotrophins and growth factors (C) analyzed in the samples taken from the core of lesions of $d b d b$ mice treated with $\mathrm{CHF} 30 \mu \mathrm{g} / \mathrm{cm}^{2}$ vs. $d b d b$ mice treated with vehicle at $50 \%$ of closure. The table of the differentially expressed genes (fold of change $>3$ ) is included in each graph. (D) STRING software analysis of protein interactions. Proteins coded by the differentially expressed genes were included in the analysis and a first shell of interacting proteins was added. (E and F) Ulcerinduced variation expression of Akt protein levels quantified (E). Quantification was performed by Western blot on samples taken from core of ulcers $(6 \mathrm{~mm})$ of animals treated with vehicle or CHF6467 $(n=6)$ and on intact skin of the same animals $(n=3)(\mathrm{F})$. Akt quantification was normalized on $\beta$-actin levels for each sample, and the obtained Akt levels of ulcers were further normalized on intact skin values to obtain the variation index [intact skin $=1$, horizontal dotted line in graph (E)]. Statistical analysis. Student's $t$ test, ${ }^{* *} P<0.01$. Ctgf, connective tissue growth factor; Hifla, hypoxia-inducible factor 1- $\alpha$; Tnc, Tenascin C. 
The log-rank analysis of the healing curves indicated that all three doses $\left(1,10\right.$, and $\left.100 \mu \mathrm{g} / \mathrm{cm}^{2}\right)$ of topical CHF6467 significantly accelerated the healing process compared with vehicle (Fig. 5C), with 35 out of 36 skin lesions (97\%) healed at day 28 in the $10 \mu \mathrm{g} / \mathrm{cm}^{2}$ group.

Pain Threshold. Thermal hyperalgesia results are shown in Fig. 5D. A significant reduction in paw withdrawal latency was observed in CHF6467 $1 \mu \mathrm{g} / \mathrm{cm}^{2}$ compared with vehicletreated mice. No hyperalgesia to thermal stimuli was observed in the other groups. Local mechanical hyperalgesia was also evaluated the day after the final test compound application (on day 15). No hyperalgesia to locally applied mechanic stimuli was observed in the CHF6467-treated groups (unpublished data).

Histology and Immunohistochemistry. Samples of the skin containing the area of the ulcer, including a margin of intact skin, were excised, embedded in paraffin, serially sectioned to obtain the "equator" of the repaired ulcer, and stained for HE. A representative low-power image at the ulcer "equator" at sacrifice is shown in Fig. 6A. The histologic structure of the epidermis, derma, and hypodermis of the intact skin (peripheral parts) is shown, including the ulcer area (rectangle), where the epidermis is visible, but the derma is still incompletely restored, as indicated by the prevalence of collagen fibers and the paucity of dermal annexes (glands and hair follicles). The re-epithelization was analyzed by measuring the epidermal thickness at the equator of the lesioned area. Representative images in vehicle- and CHF6467-treated animals and respective results are shown in Fig. 6, B-F. The histologic analysis confirmed the clinical data (Supplemental Table 2), showing that the new epidermal layer is complete in 18 out of 30 ulcers in vehicle-treated mice, in 29 out of 36 ulcers in CHF6467 $1 \mu \mathrm{g} / \mathrm{cm}^{2}$-treated mice, in 35 out of 36 ulcers in CHF6467 $10 \mu \mathrm{g} / \mathrm{cm}^{2}$-treated mice, and in 32 out of 36 ulcers in CHF6467 $100 \mu \mathrm{g} / \mathrm{cm}^{2}$-treated mice. The thickness of the newly formed epidermis sampled at the lesion
A

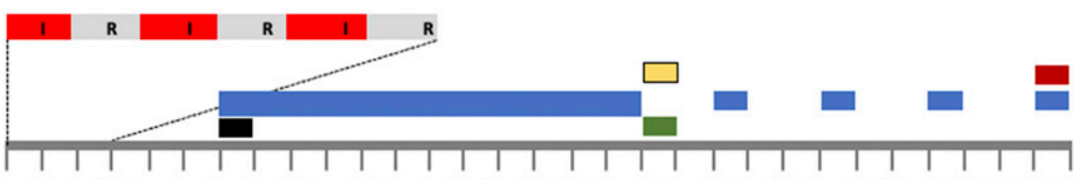

$\begin{array}{llllllllllllllllllllllllllllll}-3 & -2 & -1 & 0 & 1 & 2 & 3 & 4 & 5 & 6 & 7 & 8 & 9 & 10 & 11 & 12 & 13 & 14 & 15 & 16 & 17 & 18 & 19 & 20 & 21 & 22 & 23 & 24 & 25 & 26 \\ \exp & \text { day }\end{array}$

ischemia riperfusion surgical curettage
CHF64/67 or vehicle treatment CHF6467 plasma assay sacrifice

B

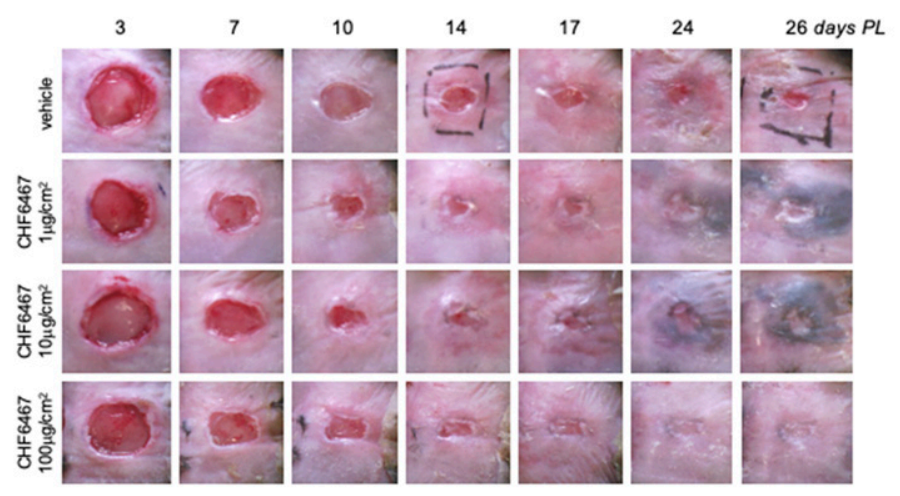

C

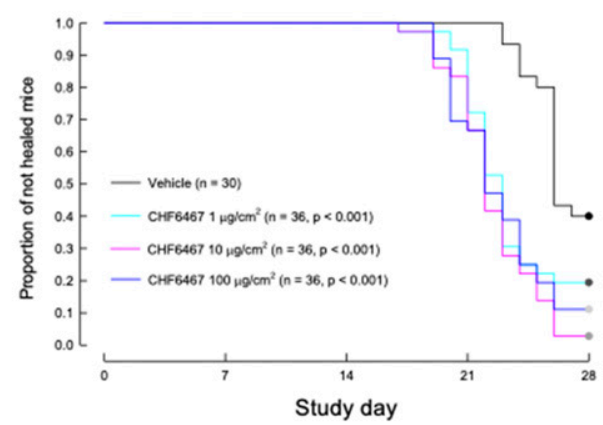

D

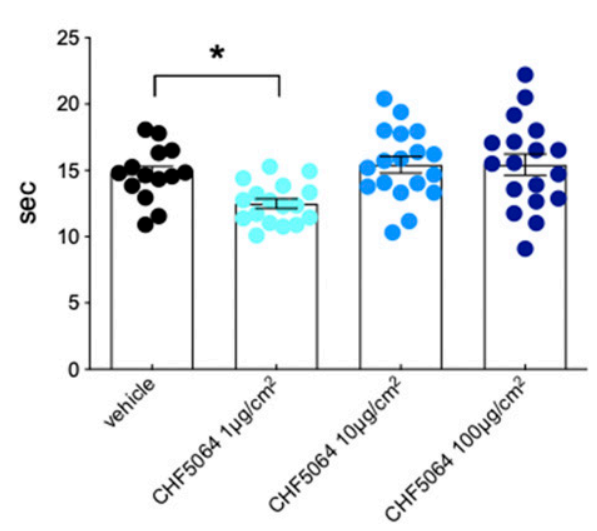

Fig. 5. Pressure-ulcer lesion: schedule of the experiment and healing curve; exp day (experimental day) (A) Schedule of the experiment. (B) Representative photos of the ulcers at different postlesion times in vehicle-treated and CHF6467 1, $10,30 \mu \mathrm{g} / \mathrm{cm}^{2}$-treated $d b d b$ mice; days PL (days Post lesion) (C) Kaplan-Meier curve expressing the nonhealing probability in the experimental groups. (D) Thermal hyperalgesia measured at day 15 in all experimental groups. Statistical analysis: one-way ANOVA and Dunnett's post hoc test, $* P<0.05$. 
equator progressively increased in a dose-dependent trend in CHF6467-treated mice compared with vehicle, resulting in it being significantly thicker in CHF6467 $100 \mu \mathrm{g} / \mathrm{cm}^{2}$-treated mice (Student's $t$ test, vehicle vs. CHF6467 $100 \mu \mathrm{g} / \mathrm{cm}^{2}, P=$ 0.0347).

The effect of topical CHF6467 application on nerve-ending regrowth in the repaired skin has been analyzed as PGP9.5-IR in the epidermal papillae of the repaired area. Representative images and results from the morphometric analysis are given in Fig. 6, G-K, respectively. A slight dose-dependent increase in innervation is observed [one-way $\operatorname{ANOVA,~} \mathrm{F}(3,63)=$ 3.716, $P=0.016$ ], resulting in a significant effect in CHF6467 $100 \mu \mathrm{g} / \mathrm{cm}^{2}$-treated mice.

The effect of topical CHF6467 application on angiogenesis was estimated using PECAM-1 (CD31) as a marker.
Representative images and results from the morphometric analysis are shown in Fig. 6, L-P. An increase in capillary density, as evaluated by PECAM-1-IR, is observed in the dermis of CHF6467-treated mice [one-way ANOVA, F $(3,63)=$ 15.48, $P<0.0001$ ], resulting in a significant effect in $\mathrm{CHF} 6467$ $10 \mu \mathrm{g} / \mathrm{cm}^{2}-$ and CHF6467 $100 \mu \mathrm{g} / \mathrm{cm}^{2}$-treated mice.

\section{CHF6467 Effect on In Vitro Population Doubling of HEK and BJ Cells and Angiogenesis Assays in HUVEC Cells}

The aim of these experiments was to investigate the effect of CHF6467 on three different cell types involved in the wound healing process (i.e., keratinocytes, fibroblasts, and endothelial cells), considering proliferation and in vitro angiogenesis as respective readouts. We used three extensively used human

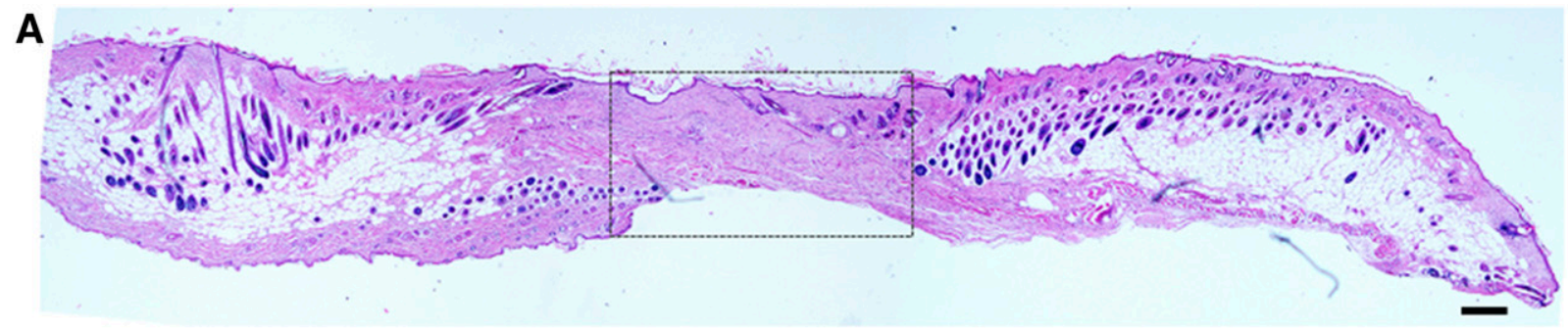

vehicle
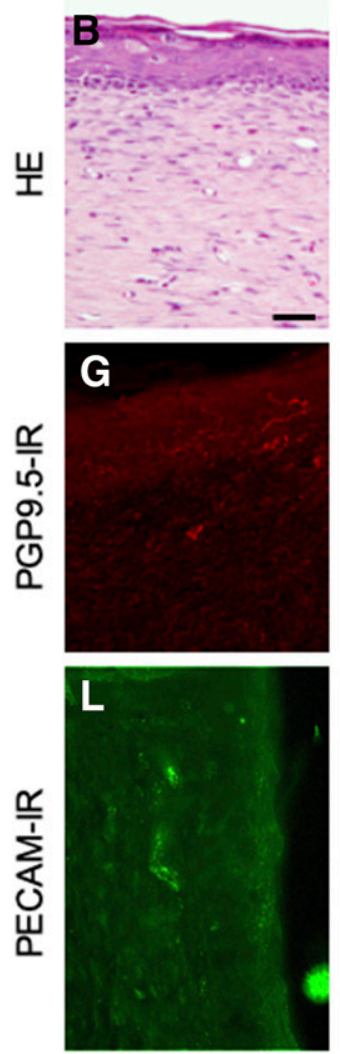

CHF6467 $1 \mu \mathrm{g} / \mathrm{cm}^{2}$
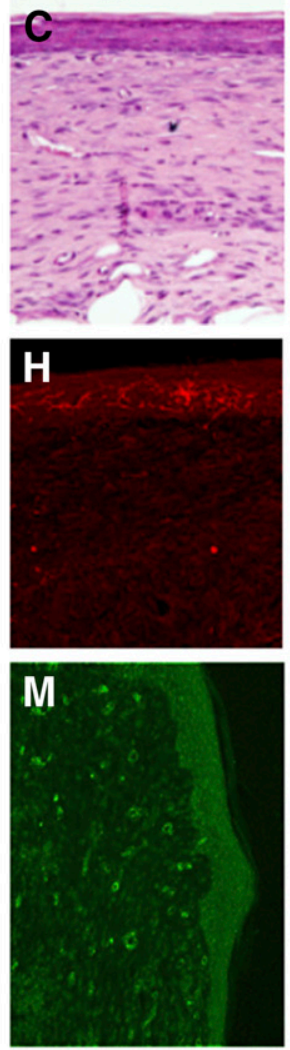
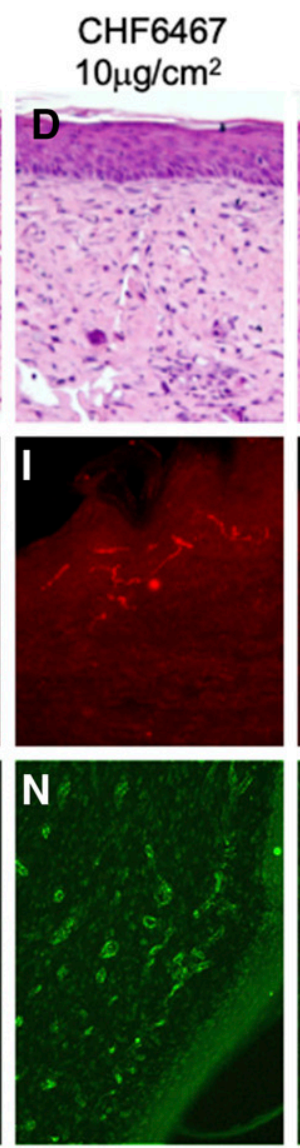

CHF6467 $100 \mu \mathrm{g} / \mathrm{cm}^{2}$
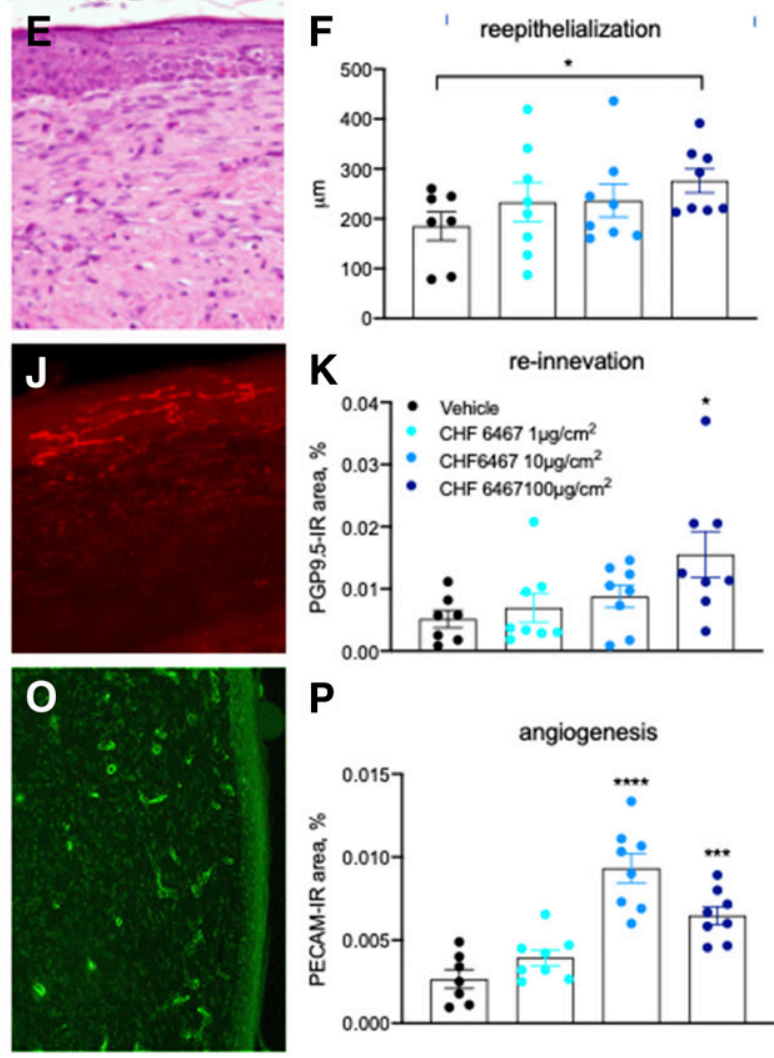

$\mathbf{P}$

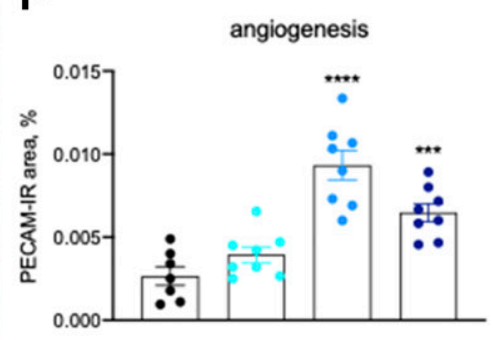

Fig. 6. Histologic and immunohistochemical analysis of the skin in the pressure-ulcer model. (A) HE staining of the skin biopsy at experimental day 28 , showing the central area (dotted square) considered for morphometry. (B-F) Representative HE-stained section of the repaired skin in vehicle-treated (B) and CHF6467 1 (C), 10 (D), $100 \mu \mathrm{g} / \mathrm{cm}^{2}-$ (E) treated $d b d b$ mice and morphometric evaluation of epidermal thickness (F). (G-K) Representative micrographs of PGP9.5-IR fibers in vehicle-treated (G) and CHF6467 $1(\mathrm{H}), 10(\mathrm{I}), 100 \mu \mathrm{g} / \mathrm{cm}^{2}-(\mathrm{J})$ treated $d b d b$ mice and morphometric evaluation of PGP9.5-positive percentage area (K). (L-P) Representative micrographs of PECAM-1-IR in repaired skin in vehicle-treated (L) and CHF6467 1 (M), 10 $(\mathrm{N}), 100 \mu \mathrm{g} / \mathrm{cm}^{2}-(\mathrm{O})$ treated $d b d b$ mice and morphometric evaluation of PECAM-1-positive percentage area (P). Statistical analysis: one-way ANOVA and Dunnett's post hoc test, ${ }^{*} P<0.05$; ** $P<0.01$; **** $P<0.0001$. Scale bars, (A and D) $500 \mu \mathrm{m}$; (B and O) $50 \mu \mathrm{m}$. 
cell lines (i.e., HEK keratinocytes, BJ fibroblasts, and HUVEC endothelial cells). Figure 7, A and B illustrate HEK cultures in the investigated experimental conditions. CHF6467 induced a concentration-dependent increase in cell proliferation up to the 192-hour time point [two-way ANOVA, treatment $\mathrm{F}(3,100) P<0.0001$, time $\mathrm{F}(4,100) P<0.0001$, interaction F(12, 100) $P<0.0001]$ compared with the respective vehicle, and at the last time point, all tested CHF6467 concentrations resulted in increased cell numbers compared with the vehicle-treated group (Dunnett's post hoc; 50,100 , and $200 \mathrm{ng} / \mathrm{ml}, P<0.0001$ ) (Fig. 7C).

Figure 7, D and E illustrate BJ cultures in the investigated experimental conditions. CHF6467 induced a concentrationdependent increase in cell proliferation in fibroblasts compared with the respective vehicle up to the 240 -hour time point in culture [two-way ANOVA, treatment $\mathrm{F}(3,100) P<0.0001$, time $\mathrm{F}(4,100) P<0.0001$, interaction $\mathrm{F}(12,100) P<0.0001$, and at the last time point, only the highest concentration of CHF6467 (200 ng/ml) produced an increase in cell number compared with cells exposed to vehicle (Dunnett's post hoc, $P<0.0001$ ) (Fig. 7F).

The effect of CHF6467 on angiogenesis was tested on HUVEC cells stained for actin using the conventional angiogenic assay protocol for cell growth and analysis. DAPT $5 \mu \mathrm{M}$ was used as reference compound. Figure 7, G and $\mathrm{H}$ illustrate the effect of $\mathrm{CHF} 6467$ at the highest tested dose on angiogenesis $(\mathrm{H})$ compared with vehicle-treated cells $(\mathrm{G})$. The results indicate robust proangiogenic effects of CHF6467 [Fig. 7I; oneway ANOVA, $\mathrm{F}(4,5)=13.89, P=0.0064]$, whose response at 100 and $200 \mathrm{nM}$ (Dunnett's post-test, compared with vehicle,
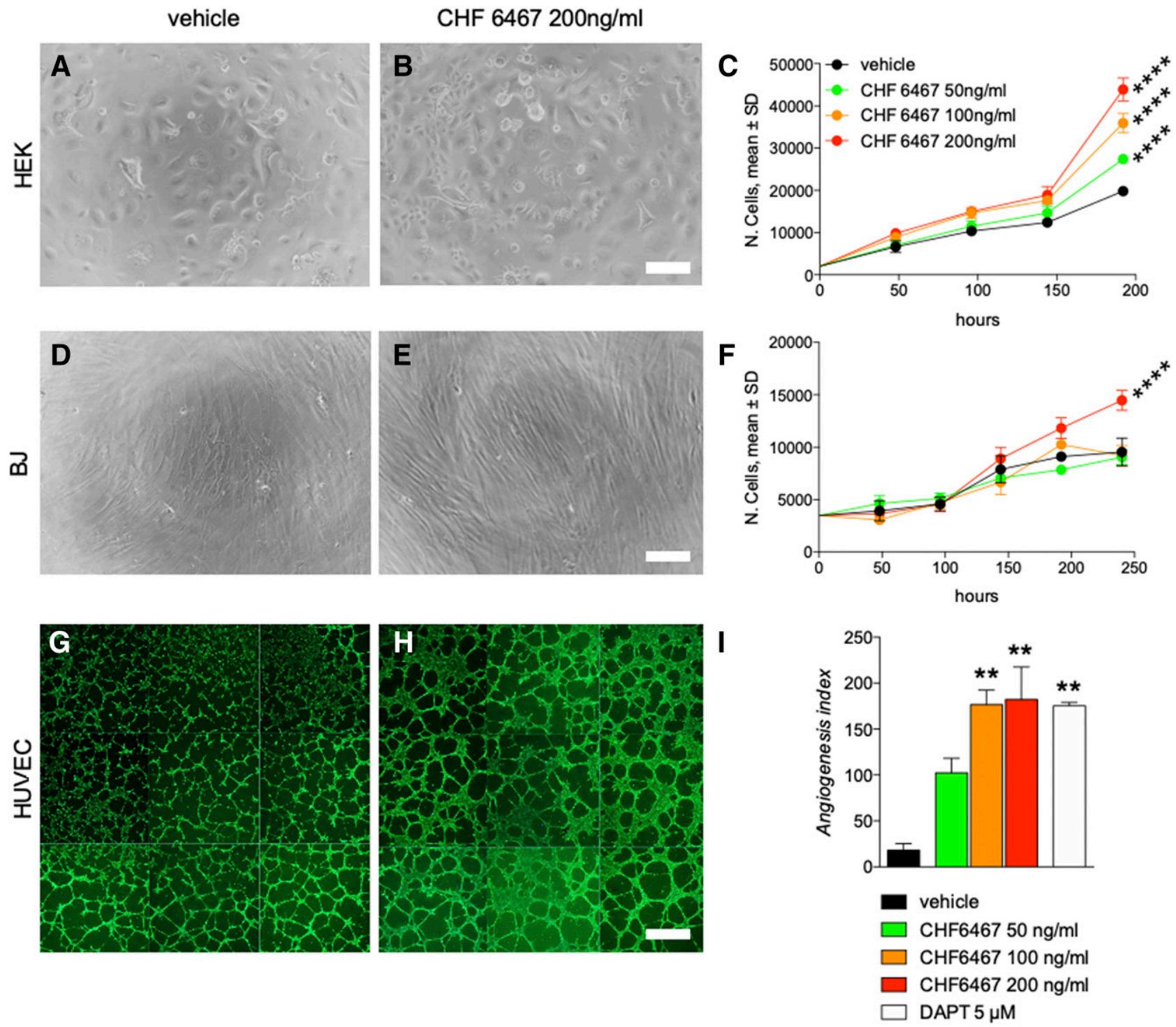

Fig. 7. Effect of CHF6467 exposure in human cell cultures. (A-C) Representative images of HEK cells exposed to vehicle (A) or CHF6467 $200 \mathrm{ng} / \mathrm{ml}$ (B) at 192 hours in cultures and quantification of cell number at five different time points (every 48 hours) of cells exposed to vehicle or CHF6467 at three different concentrations [50, 100, $200 \mathrm{ng} / \mathrm{ml}$; (C)]. Scale bar, $20 \mu \mathrm{m}$. (D-F) Representative images of BJ cells exposed to vehicle (D) or CHF6467 $200 \mathrm{ng} / \mathrm{ml}$ (F) at 240 hours in cultures and quantification of cell number at six different time points (every 48 hours) of cells exposed to vehicle or CHF6467 at three different concentrations [50, 100, $200 \mathrm{ng} / \mathrm{ml}$; (F)]. Scale bar, $20 \mu \mathrm{m}$. (G-I) Representative images (cell-based HCS montage representing the whole well) of HUVEC cells exposed to vehicle (G) or CHF6467 $200 \mathrm{ng} / \mathrm{ml}(\mathrm{H})$ and quantification of angiogenesis index at 8 hours of cells exposed to vehicle or CHF6467 at three different concentrations [50, 100, $200 \mathrm{ng} / \mathrm{ml}$; (F)]. Scale bar, $200 \mu \mathrm{m}$. Statistical analysis. Two-way ANOVA (C and F) or one-way ANOVA (I) followed by Dunnett's post hoc. Asterisks represent differences compared with vehicle-treated cultures $(* * P<0.01 ; * * * * P>0.0001)$. 
$100 \mathrm{ng} / \mathrm{ml}, P=0.006 ; 200 \mathrm{ng} / \mathrm{ml}, P=0.0051)$ was similar to the DAPT reference compound (Dunnett's post hoc, compared with vehicle, $P=0.0062$ ).

To further support the mechanism identified by the bioinformatic analysis and confirmed by the protein analysis in the skin, we also quantified the Akt protein in BJ and HUVEC cell high-glucose cultures treated with vehicle or the highest dose of CHF6467 for 48 hours (200 ng/ml). BJ cultures (Fig. 8A) show a decrease in Akt protein quantity when treated with CHF6467 (Student's $t$ test, $P=0.0071$; Fig. 8, B and $\mathrm{C}$ ), whereas the same treatment in HUVEC (Fig. 8D) resulted in no change in protein level (Fig. 8, E and F).

\section{Potential Tumorigenic Effect: Exploratory Study}

To explore whether topical application of CHF6467 and the stimulating effect on cell proliferation activate aberrant, cancer-related pathways, we performed a pathway-focused gene expression analysis on tissue samples obtained immediately after CHF6467 discontinuation (day 14) corresponding to $50 \%-70 \%$ of the repair process (see Supplemental Table 3, for the list of the investigated genes). The expression analysis was performed considering only the mean expression of $B 2 m$ (beta 2-microglobulin), or Acly (ATP cytrate lysate), Xrcc4 (X-ray repair cross-complementing protein 4), Casp2 (caspase 2), Stmn1 (stathmin 1), Igfbp3 (insulin-like growth factor-binding protein 3) as housekeeping genes, according to the Qiagen data analysis software recommendation. In both cases, the expression level of only 1 of the 84 genes ( $E r c c 3$, excision repair crosscomplementation group 3) was downregulated at the $100 \mu \mathrm{g} / \mathrm{cm}^{2}$ concentration of CHF6467 (Supplemental Fig. 2), whereas the expression of the other genes was unchanged.

\section{Discussion}

In this study, we showed that the topical application of CHF6467, a nonalgogenic derivative of human NGF, accelerates skin repair in experimental wounds induced in diabetic mice. The main results of the study can be summarized as follows: 1) CHF6467 accelerates wound healing in both the full-thickness skin-excision model and in the model of pressure ulcer induced by repeated ischemia-reperfusion cycles; 2) topical CHF6467 application does not induce systemic thermal or local mechanical hyperalgesia; 3) CHF6467 improves re-epithelization, reinnervation, and revascularization, as assessed by histology, immunohistochemistry, and image analysis; 4) the underlying molecular mechanisms involve the Akt-mTOR pathway; 5) when tested in vitro in human cell lines, CHF6467 stimulates keratinocyte and fibroblast proliferation and tube formation by endothelial cells.

The study was performed in $d b d b$ mice, the most widely used mouse model of type 2 diabetes mellitus (Alpers and Hudkins, 2011). These mice develop progressive sensory loss, electrophysiological impairments, and skin innervation loss (De Gregorio et al., 2018) as well as hyperalgesia to thermal and mechanical stimuli (Shi et al., 2013; Tang et al., 2019), which are aspects that reflect at least some of the features observed in human diabetic neuropathy (Yorek, 2016).

Wound healing in $d b d b$ mice includes all phases of the process: inflammation (phase 1); proliferation (including reepithelization), granulation tissue formation mainly by fibroblasts, and neovascularization (phase 2); and remodeling, with scar maturation and reorganization of the extracellular matrix (phase 3 ). However, the repair process is much slower in $d b d b$ than in $d b /$-, particularly in wounds covered by Tegaderm as in our experimental conditions
A

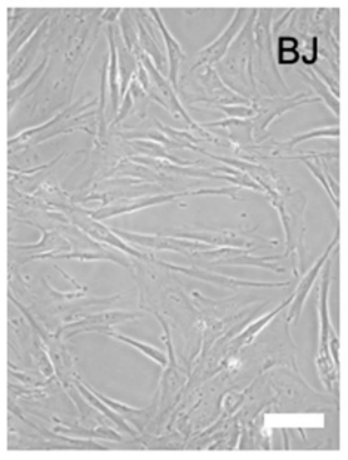

D

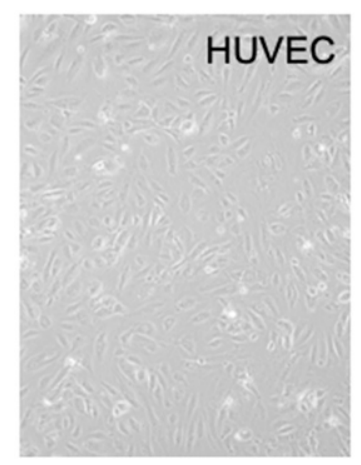

B

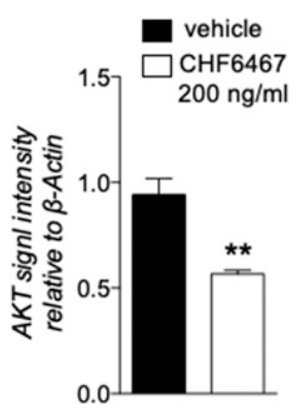

E

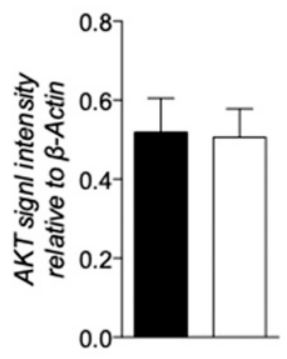

C

vehicle CHF6467

$60 \mathrm{KDa}$ AKT

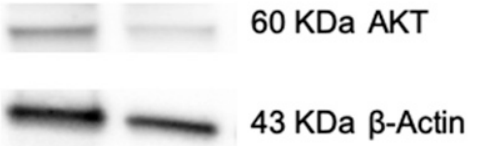

$\mathbf{F}$

vehicle $\mathrm{CHF6467}$
Fig. 8. Akt protein quantification in cell cultures. (A-C) Akt protein level quantification in BJ cell high-glucose cultures (A) exposed to vehicle or CHF6467200 ng/ $\mathrm{ml}$ (B) by Western blot (C). (D-F) Akt protein level quantification in HUVEC high-glucose cultures (D) exposed to vehicle or CHF6467 $200 \mathrm{ng} / \mathrm{ml}$ (E) by Western blot (F). Scale bar, $10 \mu \mathrm{m}$. Statistical analysis. Student's $t$ test, $* * P<0.01$
$60 \mathrm{KDa}$ AKT

$43 \mathrm{KDa} \beta$-Actin

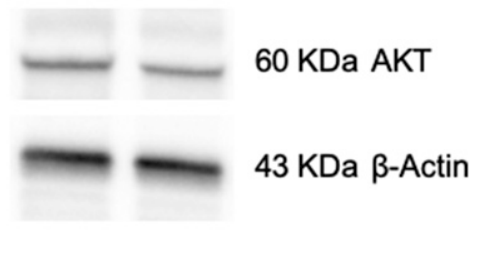


(Sullivan et al., 2007), making this mouse model very appropriate for testing prohealing compounds.

We observed that the topical application of CHF6467 accelerated wound healing in both ulcer models in $d b d b$ mice. Given the different pathogenic mechanisms supporting the ulcer (surgery and ischemia/reperfusion, respectively) and the differences in ulcer severity, we used two different application schemes. In the full-thickness ulcer, in which the lesion diameter was around $6 \mathrm{~mm}$, we applied CHF6467 for seven consecutive days starting immediately after lesion induction, therefore during the inflammatory phase of the process. In the pressure ulcers in which the lesion diameter was around $12 \mathrm{~mm}$ after debriding, we applied CHF6467 for 12 consecutive days, then every 2 days up to day 26 , therefore in the inflammatory but also in the proliferative phase of the process.

In the full-thickness skin-excision model, the healing curve in the CHF6467-treated animal began to differ from the other groups at 11 days postlesion, and healing was complete in almost all animals treated with 10 and $30 \mu \mathrm{g} / \mathrm{cm}^{2}$ of CHF6467 at 18 days postlesion. Histologic and immunohistochemical analysis reveals that NGF treatment (with native mouse and human forms of NGF and CHF6467) improves re-epithelization, reinnervation, and angiogenesis in the repaired skin, confirming the previously described effects of the biologically active $2.5 \mathrm{~S}$ NGF subunit on wound healing in full-thickness excision lesions in diabetic mice (Muangman et al., 2004).

To confirm the effectiveness of CHF6467 in skin wound healing in diabetic mice, we tested three different dosages (1, $\left.10,100 \mu \mathrm{g} / \mathrm{cm}^{2}\right)$ in a pressure-ulcer model based on ischemiareperfusion cycles (Stadler et al., 2004; Huggenberger and Detmar, 2011), a model that has also been used to test new pharmacological and nonpharmacological treatments in $d b d b$ mice (Cronk et al., 2015; Danigo et al., 2015; Duscher et al., 2015). Topical CHF6467 application accelerated the healing rate and time of ulcer repair, also stimulating reepithelization, reinnervation, and angiogenesis processes in this model.

Notably, none of the CHF6467 doses decreased the pain threshold measured 24 hours after the final application, despite the dose-dependent increase in total plasma NGF levels compared with baseline, an increase that was transient and normalized 22 days after CHF6467/NGF treatment withdrawal. On the contrary, an increase in pain sensitivity was observed in hrNGF-treated mice, allowing us to conclude that transdermal absorption of the mutated NGF CHF6467 does not induce pain threshold variations for thermal stimuli after multiple-dose administration.

From these experiments, we can conclude that the topical application of CHF6467, a modified human recombinant NGF that does not elicit hyperalgesia at therapeutic doses, accelerates wound healing in diabetic mice. Improved reinnervation of the wound area may be a supporting mechanism: Indeed, a central rationale for using NGF to promote healing in diabetes stems from a feature of the disease known as "small-fiber neuropathy" and is characterized by a reduced number of nerve endings in the epidermis (Ebenezer and Polydefkis, 2014). Appropriate skin innervation plays a preeminent role in wound healing (Kiya and Kubo, 2019), and a reduction in neurotrophic support to peripheral neurons has been described in diabetic skin (Sima, 2003). NGF is the neurotrophin responsible for establishing sensory innervation of the skin during development and for its maintenance in adulthood (Indo, 2010). Thus, the topical application of NGF has been considered as a possible therapy for accelerating skin wound healing in pressure ulcers (Aloe, 2004) and postchronic vasculitis ulcers (Tuveri et al., 2000).

Several cell types in the skin are NGF-sensitive (Sofroniew et al., 2001) and may be involved in the positive effect on wound healing exerted by the topical application of CHF6467. CHF6467, when applied in vitro, induces a concentrationdependent increase in keratinocyte and fibroblast proliferation. This confirms recent results demonstrating that moNGF stimulates in vitro keratinocyte proliferation and migration and reverses the impairment induced by high d-glucose concentrations in the culture medium (Gostynska et al., 2020).

NGF plays a role in angiogenesis, as suggested by in vivo studies in several tissues under physiologic and pathologic conditions. It also promotes VEGF synthesis and secretion (Calzà et al., 2001; Ahluwalia et al., 2018; Li et al., 2018); indeed, an NGF defect has been associated with impaired angiogenesis and defective mucosa repair (Ahluwalia et al., 2018). A protective and proangiogenic role of NGF on endothelial cells has been also described in vitro (Ahluwalia et al., 2017; Lazarovici et al., 2018), and we demonstrated that both moNGF and CHF6467 increase endothelial cell proliferation and in vitro angiogenesis in a concentration-dependent manner as well as restore the tube-formation capacity disrupted by high-glucose concentrations in the culture medium (Gostynska et al., 2020).

Given the substantial hypertrophy observed in repaired skin epithelium, and the disputed role of NGF in cancer (Demir et al., 2016), we also explored the regulation of 80 cancer-related genes at $50 \%$ of the wound healing process in the pressure-ulcer model. The only downregulated gene in mice treated with the highest CHF6467 dose was excision repair crosscomplementation group 3, a gene involved in DNA repair but also in hair-follicle physiology (Yu et al., 2012).

Wound healing involves dozens of molecules that interact with the different cell types concerned. We therefore adopted an exploratory, bioinformatic strategy to identify possible primary molecular pathways involved in the prohealing effect of CHF6467, comparing gene expression regulation in CHF6467 and vehicle-treated mice in the full-thickness excision model at $50 \%$ of the repair process, when ECM deposition, keratinocyte proliferation, and angiogenesis occur simultaneously. From the analysis of 240 genes related to angiogenesis, ECM, and growth factors, we observed that $M m p 9$, an enzyme involved in tissue remodeling and required for the recruitment of endothelial stem cells during angiogenesis (Heissig et al., 2002), is upregulated in CHF6467-treated mice compared with vehicle-treated mice. Conversely, Akt1, chemokine (C-C motif) ligand 2, connective tissue growth factor, hypoxia-inducible factor 1- $\alpha, M m p 14$, Thbs2, and Tenascin were all downregulated by CHF6467 treatment. Notably, a hyperactivity of these genes seems to play a role in pathologic wound healing in diabetes and other conditions (Bornstein et al., 2000; Botusan et al., 2008; Liu et al., 2012; Ishikawa et al., 2015; Catrina and Zheng, 2016; Zigrino et al., 2016; Abu El-Asrar et al., 2018; Gale et al., 2018; Kunkemoeller et al., 2019).

The bioinformatic analysis performed by STRING software indicates that the Akt-mTOR pathway is involved in the 
prohealing effects of CHF6467, as also confirmed by protein analysis, and fibroblasts are the cells in which this regulation occurs. Akt and mTOR are considered survival and cellular growth in response to lesions. NGF via trkA activates PI3K/ Akt and ERK (extracellular signal-regulated kinase)/MAPK (mitogen-activated protein kinase) signaling pathways and the downstream mTOR, and this pathway mediates several NGF effects, such as endothelial cell invasion and cord formation during development (Park et al., 2007), angiogenesis in subchondral bone (Yu et al., 2019), and neuroprotection (Elsherbiny et al., 2019). Moreover, NGF-enhanced secretion of VEGF is also mediated by the extracellular signal-regulated kinases 1/2 and PI3K/Akt pathways (Wang et al., 2016). An impairment of the Akt-mTOR pathway has been indicated as a possible cause of wound healing impairment in diabetic mice (Huang et al., 2015; Jere et al., 2019), and transient pharmacological activation of the PI3K-Akt-mTOR signaling axis has been considered a novel clinical intervention strategy to accelerate wound (ulcer) healing (Squarize et al., 2010).

In conclusion, we showed that the topical application of CHF6467, a nonalgogenic hrNGF derivative, accelerates skin wound healing in diabetic mice in both full-thickness excision and pressure-ulcer models, also improving angiogenesis and reinnervation without inducing hyperalgesia. We suggest that the Akt/mTOR pathway may be activated by CHF6467.

\section{Acknowledgments}

Dr. Natalia Gostynska is gratefully acknowledged for the BJ experiments. All data sets are available to the corresponding author upon reasonable request.

\section{Authorship Contributions}

Participated in research design: Villetti, Imbimbo, Giardino, Calzà. Conducted experiments: Giuliani, Lorenzini, Pannella, Cescatti, Fernandez, Alastra, Flagelli.

Contributed new reagents or analytic tools: Villetti.

Performed data analysis: Giuliani, Lorenzini, Baldassarro, Pannella, Cescatti, Fernandez, Alastra, Flagelli, Villetti, Imbimbo, Giardano, Calzà.

Wrote or contributed to the writing of the manuscript: Baldassarro, Villetti, Imbimbo, Giardano, Calzà.

\section{References}

Abu El-Asrar AM, Mohammad G, Allegaert E, Ahmad A, Siddiquei MM, Alam K, Gikandi PW, De Hertogh G, and Opdenakker G (2018) Matrix metalloproteinase14 is a biomarker of angiogenic activity in proliferative diabetic retinopathy. Mol Vis 24:394-406.

Ahluwalia A, Jones MK, Hoa N, and Tarnawski AS (2017) NGF protects endothelial cells from indomethacin-induced injury through activation of mitochondria and upregulation of IGF-1. Cell Signal 40:22-29 DOI: 10.1016/j.cellsig.2017.08.006.

Ahluwalia A, Jones MK, Hoa N, Zhu E, Brzozowski T, and Tarnawski AS (2018) Reduced NGF in gastric endothelial cells is one of the main causes of impaired angiogenesis in aging gastric mucosa. Cell Mol Gastroenterol Hepatol 6:199-213 DOI: $10.1016 /$ j.jcmgh.2018.05.003.

Aloe L (2004) Nerve growth factor, human skin ulcers and vascularization. Our experience. Prog Brain Res 146:515-522.

Aloe L and Calzà L (2004) NGF and related molecules in health and disease: preface. Prog Brain Res 146:544.

Alpers and Hudkins (2011) Mouse models of diabetic nephropathy. Curr Opin Neurophrol Hypertens, doi: 10.1097/MNH.0b013e3283451901 21422926.

Bagal SK, Omoto K, Blakemore DC, Bungay PJ, Bilsland JG, Clarke PJ, Corbett MS, Cronin CN, Cui JJ, Dias R, et al. (2019) Discovery of allosteric, potent, subtype selective, and peripherally restricted TrkA kinase inhibitors. J Med Chem 62: 247-265 DOI: 10.1021/acs.jmedchem.8b00280.

Blume P and Wu S (2018) Updating the diabetic foot treatment algorithm: recommendations on treatment using advanced medicine and therapies. Wounds $\mathbf{3 0}$ $29-35$.

Bornstein P, Kyriakides TR, Yang Z, Armstrong LC, and Birk DE (2000) Thrombospondin 2 modulates collagen fibrillogenesis and angiogenesis. J Investig Dermatol Symp Proc 5:61-66 DOI: 10.1046/j.1087-0024.2000.00005.x.

Botusan IR, Sunkari VG, Savu O, Catrina AI, Grünler J, Lindberg S, Pereira T, YläHerttuala S, Poellinger L, Brismar K, et al. (2008) Stabilization of HIF-1 $\alpha$ is critical to improve wound healing in diabetic mice. Proc Natl Acad Sci USA 105 19426-19431 DOI: 10.1073/pnas.0805230105.

Calzà L, Giardino L, Giuliani A, Aloe L, and Levi-Montalcini R (2001) Nerve growth factor control of neuronal expression of angiogenetic and vasoactive factors. Proc Natl Acad Sci USA 98:4160-4165 DOI: 10.1073/pnas.051626998.

Calzà L, Giardino L, Pozza M, Micera A, and Aloe L (1997) Time-course changes of nerve growth factor, corticotropin-releasing hormone, and nitric oxide synthase isoforms and their possible role in the development of inflammatory response in experimental allergic encephalomyelitis. Proc Natl Acad Sci USA 94:3368-3373 DOI: $10.1073 /$ pnas.94.7.3368

Carleton LA, Chakravarthy R, van der Sloot AM, Mnich K, Serrano L, Samali A and Gorman AM (2018) Generation of rationally-designed nerve growth factor (NGF) variants with receptor specificity. Biochem Biophys Res Commun 495: 700-705 DOI: 10.1016/j.bbrc.2017.11.003

Catrina SB and Zheng X (2016) Disturbed hypoxic responses as a pathogenic mechanism of diabetic foot ulcers. Diabetes Metab Res Rev 32 (Suppl 1):179-185 DOI: $10.1002 /$ dmrr.2742

Cattaneo A. and Capsoni S. (2019) A TrkA biased agonist mediating a broad neuroprotection via its actions on microglia cells. Pharmacol Res 139:17-25.

Chéret J, Lebonvallet N, Carré JL, Misery L, and Le Gall-Ianotto C (2013) Role of neuropeptides, neurotrophins, and neurohormones in skin wound healing. Wound Repair Regen 21:772-788.

Cronk SM, Kelly-Goss MR, Ray HC, Mendel TA, Hoehn KL, Bruce AC, Dey BK, Guendel AM, Tavakol DN, Herman IM, et al. (2015) Adipose-derived stem cells from diabetic mice show impaired vascular stabilization in a murine model of diabetic retinopathy. Stem Cells Transl Med 4:459-467 DOI: 10.5966/sctm.20140108 .

Danigo A, Nasser M, Bessaguet F, Javellaud J, Oudart N, Achard JM, and Demiot C (2015) Candesartan restores pressure-induced vasodilation and prevents skin pressure ulcer formation in diabetic mice. Cardiovasc Diabetol 14:26 DOI: 10.1186/ s12933-015-0185-4.

De Gregorio C, Contador D, Campero M, Ezquer M, and Ezquer F (2018) Characterization of diabetic neuropathy progression in a mouse model of type 2 diabetes mellitus. Biol Open 7:bio036830 DOI: 10.1242/bio.036830

Demir IE, Tieftrunk E, Schorn S, Friess H, and Ceyhan GO (2016) Nerve growth factor \& TrkA as novel therapeutic targets in cancer. Biochim Biophys Acta 1866: $37-50$

Duscher D, Neofytou E, Wong VW, Maan ZN, Rennert RC, Inayathullah M, Januszyk M, Rodrigues M, Malkovskiy AV, Whitmore AJ, et al. (2015) Transdermal deferoxamine prevents pressure-induced diabetic ulcers. Proc Natl Acad Sci USA 112: 94-99 DOI: 10.1073/pnas.1413445112.

Ebenezer G and Polydefkis M (2014) Epidermal innervation in diabetes, Handbook of Clinical Neurology, Douglas W. Zochodne, Rayaz A. Malik (eds.) vol. 126, pp 261-274, Elsevier B.V., Amsterdam.

Einarsdottir E, Carlsson A, Minde J, Toolanen G, Svensson O, Solders G, Holmgren G, Holmberg D, and Holmberg M (2004) A mutation in the nerve growth factor beta gene (NGFB) causes loss of pain perception. Hum Mol Genet 13:799-805 DOI: $10.1093 / \mathrm{hmg} / \mathrm{ddh} 096$

Elsherbiny NM, Abdel-Mottaleb Y, Elkazaz AY, Atef H, Lashine RM, Youssef AM, Ezzat W, El-Ghaiesh SH, Elshaer RE, El-Shafey M, et al. (2019) Carbamazepine alleviates retinal and optic nerve neural degeneration in diabetic mice via nerve growth factor-induced PI3K/Akt/mTOR activation. Front Neurosci 13:1089 DOI 10.3389 /fnins.2019.01089.

Everett E and Mathioudakis N (2018) Update on management of diabetic foot ulcers. Ann N Y Acad Sci 1411:153-165.

Gale JD, Jensen J, Berman G, Freimuth W, Li G, Pleil A, Kutty M, Rosenthal A, Boswell CB, Noah VEM, et al. (2018) A placebo-controlled study of PF-06473871 (anti-connective tissue growth factor antisense oligonucleotide) in reducing hypertrophic skin scarring. Plast Reconstr Surg Glob Open 6:e1861 DOI: 10.1097/ gox.0000000000001861.

Gostynska N, Pannella M, Rocco ML, Giardino L, Aloe L, and Calzà L (2020) The pleiotropic molecule NGF regulates the in vitro properties of fibroblasts, keratinocytes, and endothelial cells: implications for wound healing. Am J Physiol Physiol cell Physiol 318:C360-C371 DOI: 10.1152/ajpcell.00180.2019.

Heissig B, Hattori K, Dias S, Friedrich M, Ferris B, Hackett NR, Crystal RG, Besmer P, Lyden D, Moore MAS, et al. (2002) Recruitment of stem and progenitor cells from the bone marrow niche requires MMP-9 mediated release of kit-ligand. Cell 109:625-637 DOI: 10.1016/S0092-8674(02)00754-7.

Huang H, Cui W, Qiu W, Zhu M, Zhao R, Zeng D, Dong C, Wang X, Guo W, Xing W, et al. (2015) Impaired wound healing results from the dysfunction of the Akt/mTOR pathway in diabetic rats. $J$ Dermatol Sci 79:241-251 DOI: 10.1016/ j.jdermsci.2015.06.002

Huggenberger R and Detmar M (2011) The cutaneous vascular system in chronic skin inflammation. J Investig Dermatol Symp Proc 15:24-32.

Indo Y (2010) Nerve growth factor, pain, itch and inflammation: lessons from congenital insensitivity to pain with anhidrosis. Expert Rev Neurother 10:1707-1724. Ishikawa K, Yoshida S, Kobayashi Y, Zhou Y, Nakama T, Nakao S, Sassa Y, Oshima Y, Niiro H, Akashi K, et al. (2015) Microarray analysis of gene expression in fibrovascular membranes excised from patients with proliferative diabetic retinopathy. Invest Ophthalmol Vis Sci 56:932-946 DOI: 10.1167/iovs.14-15589.

Jaul E, Barron J, Rosenzweig JP, and Menczel J (2018) An overview of co-morbidities and the development of pressure ulcers among older adults. BMC Geriatr 18:305. Jere SW, Houreld NN, and Abrahamse H (2019) Role of the PI3K/AKT (mTOR and GSK3 $\beta$ ) signalling pathway and photobiomodulation in diabetic wound healing. Cytokine Growth Factor Rev 50:52-59.

Kawamoto K and Matsuda H (2004) Nerve growth factor and wound healing. Prog Brain Res 146:369-384.

Kennedy WR, Wendelschafer-Crabb G, and Johnson T (1996) Quantitation of epidermal nerves in diabetic neuropathy. Neurology 47:1042-1048 DOI: 10.1212 WNL.47.4.1042. 
Kiya K and Kubo T (2019) Neurovascular interactions in skin wound healing. Neurochem Int 125:144-150.

Kunkemoeller B, Bancroft T, Xing H, Morris AH, Luciano AK, Wu J, FernandezHernando C, and Kyriakides TR (2019) Elevated thrombospondin 2 contributes to delayed wound healing in diabetes. Diabetes 68:2016-2023 DOI: $10.2337 / \mathrm{db} 18$ 1001.

Landi F, Aloe L, Russo A, Cesari M, Onder G, Bonini S, Carbonin PU, and Bernabei R (2003) Topical treatment of pressure ulcers with nerve growth factor: a randomized clinical trial. Ann Intern Med 139:635-641 DOI: 10.7326/0003-4819-139-8 200310210-00006.

Laverdet B, Danigo A, Girard D, Magy L, Demiot C, and Desmoulière A (2015) Skin innervation: important roles during normal and pathological cutaneous repair Histol Histopathol 30:875-892.

Lazarovici P, Lahiani A, Gincberg G, Haham D, Fluksman A, Benny O, Marcinkiewicz C, and Lelkes PI (2018) Nerve growth factor-induced angiogenesis: 1. Endothelial cell tube formation assay. Methods $\mathrm{Mol}$ Biol 1727:239-250.

Lebrun E, Tomic-Canic M, and Kirsner RS (2010) The role of surgical debridement in healing of diabetic foot ulcers. Wound Repair Regen 18:433-438 DOI: 10.1111 j.1524-475X.2010.00619.x.

Levi-Montalcini R (1987) The nerve growth factor 35 years later. Science 237: 1154-1162 DOI: $10.1126 /$ science.3306916

Lewin GR, Lechner SG, and Smith ESJ (2014) Nerve growth factor and nociception: from experimental embryology to new analgesic therapy. Handb Exp Pharmacol 220:251-282 DOI: 10.1007/978-3-642-45106-5 10

Li X, Li F, Ling L, Li C, and Zhong Y (2018) Intranasal administration of nerve growth factor promotes angiogenesis via activation of PI3K/Akt signaling following cerebral infarction in rats. Am J Transl Res 10:3481-3492.

Liu ZH, Chen LL, Deng XL, Song HJ, Liao YF, Zeng TS, Zheng J, and Li HQ (2012) Methylation status of CpG sites in the MCP-1 promoter is correlated to serum MCP-1 in Type 2 diabetes. J Endocrinol Invest 35:585-589 DOI: 10.3275/7981.

Martinengo L, Olsson M, Bajpai R, Soljak M, Upton Z, Schmidtchen A, Car J, and Järbrink K (2019) Prevalence of chronic wounds in the general population: systematic review and meta-analysis of observational studies. Ann Epidemiol 29: 8-15.

McCarthy BG, Hsieh ST, Stocks A, Hauer P, Macko C, Cornblath DR, Griffin JW, and McArthur JC (1995) Cutaneous innervation in sensory neuropathies: evaluation by skin biopsy. Neurology 45:1848-1855 DOI: 10.1212/WNL.45.10.1848.

Muangman P, Muffley LA, Anthony JP, Spenny ML, Underwood RA, Olerud JE, and Gibran NS (2004) Nerve growth factor accelerates wound healing in diabetic mice. Wound Repair Regen 12:44-52 DOI: 10.1111/j.1067-1927.2004.012110.x-1.

Nenna A, Nappi F, Dougal J, Satriano U, Chello C, Mastroianni C, Lusini M, Chello M, and Spadaccio C (2019) Sternal wound closure in the current era: the need of a tailored approach. Gen Thorac Cardiovasc Surg 67:907-916.

Nico B, Mangieri D, Benagiano V, Crivellato E, and Ribatti D (2008) Nerve growth factor as an angiogenic factor. Microvasc Res 75:135-141.

Park MJ, Kwak HJ, Lee HC, Yoo DH, Park IC, Kim MS, Lee SH, Rhee CH, and Hong SI (2007) Nerve growth factor induces endothelial cell invasion and cord formation by promoting matrix metalloproteinase-2 expression through the phosphatidylinositol 3-kinase/Akt signaling pathway and AP-2 transcription factor. J Biol Chem 282:30485-30496 DOI: 10.1074/jbc.M701081200.

Pezet S and McMahon SB (2006) Neurotrophins: mediators and modulators of pain. Annu Rev Neurosci 29:507-538.

Powers JG, Higham C, Broussard K, and Phillips TJ (2016) Wound healing and treating wounds: chronic wound care and management. J Am Acad Dermatol $\mathbf{7 4}$ 607-625, NaN-626.

Prencipe G, Minnone G, Strippoli R, De Pasquale L, Petrini S, Caiello I, Manni L, De Benedetti F, and Bracci-Laudiero L (2014) Nerve growth factor downregulates inflammatory response in human monocytes through TrkA. J Immunol 192: 3345-3354 DOI: 10.4049/jimmunol.1300825.

Radio NM, Breier JM, Shafer TJ, and Mundy WR (2008) Assessment of chemical effects on neurite outgrowth in PC12 cells using high content screening. Toxicol Sci 105:106-118 DOI: 10.1093/toxsci/kfn114.

Rodrigues BT, Vangaveti VN, and Malabu UH (2016) Prevalence and risk factors for diabetic lower limb amputation: a clinic-based case control study. J Diabetes Res 2016:5941957 DOI: 10.1155/2016/5941957.

Sacchetti M, Lambiase A, Schmidl D, Schmetterer L, Ferrari M, Mantelli F, Allegretti M, and Garhoefer G (2020) Effect of recombinant human nerve growth factor eye drops in patients with dry eye: a phase IIa, open label, multiple-dose study. $\mathrm{Br}$ J Ophthalmol 104:127-135 DOI: 10.1136/bjophthalmol-2018-312470.

Severini C, Petrocchi Passeri P, Ciotti MT, Florenzano F, Petrella C, Malerba F, Bruni B, D'Onofrio M, Arisi I, Brandi R, et al. (2017) Nerve growth factor derivative NGF61/100 promotes outgrowth of primary sensory neurons with reduced signs of nociceptive sensitization. Neuropharmacology 117:134-148 DOI: 10.1016/ j.neuropharm.2017.01.035.

Shaw JE, Sicree RA, and Zimmet PZ (2010) Global estimates of the prevalence of diabetes for 2010 and 2030. Diabetes Res Clin Pract 87:4-14.

Shi TJS, Zhang MD, Zeberg H, Nilsson J, Grünler J, Liu SX, Xiang Q, Persson J, Fried KJ, Catrina SB, et al. (2013) Coenzyme Q10 prevents peripheral neuropathy and attenuates neuron loss in the db-/db- mouse, a type 2 diabetes model. Proc Natl Acad Sci USA 110:690-695 DOI: 10.1073/pnas.1220794110.

Sima AAF (2003) New insights into the metabolic and molecular basis for diabetic neuropathy. Cell Mol Life Sci 60:2445-2464.

Snider WD and McMahon SB (1998) Tackling pain at the source: new ideas about nociceptors. Neuron 20:629-632.

Sofroniew MV, Howe CL, and Mobley WC (2001) Nerve growth factor signaling, neuroprotection, and neural repair. Annu Rev Neurosci 24:1217-1281.

Squarize CH, Castilho RM, Bugge TH, and Gutkind JS (2010) Accelerated wound healing by mTOR activation in genetically defined mouse models. PLoS One 5 e10643 DOI: 10.1371/journal.pone.0010643.

Stadler I, Zhang RY, Oskoui P, Whittaker MS, and Lanzafame RJ (2004) Development of a simple, noninvasive, clinically relevant model of pressure ulcers in the mouse. J Invest Surg 17:221-227 DOI: 10.1080/08941930490472046.

Sullivan KA, Hayes JM, Wiggin TD, Backus C, Su Oh S, Lentz SI, Brosius F III, and Feldman EL (2007) Mouse models of diabetic neuropathy. Neurobiol Dis 28: 276-285 DOI: 10.1016/j.nbd.2007.07.022.

Tang Z, Cao F, Zhang H, Tang J, Li H, Zhang Y, Feng B, and Wang H (2019) Peripheral pain is enhanced by insulin-like growth factor 1 and its receptors in a mouse model of type 2 diabetes mellitus. J Diabetes 11:309-315 DOI: 10.1111/ 1753-0407.12841.

Tuveri M, Generini S, Matucci-Cerinic M, and Aloe L (2000) NGF, a useful tool in the treatment of chronic vasculitic ulcers in rheumatoid arthritis. Lancet 356: 1739-1740 DOI: 10.1016/S0140-6736(00)03212-8.

Ullrich A, Gray A, Berman C, and Dull TJ (1983) Human $\beta$-nerve growth factor gene sequence highly homologous to that of mouse. Nature 303:821-825 DOI: 10.1038/ $303821 \mathrm{a} 0$.

Wang J, He C, Zhou T, Huang Z, Zhou L, and Liu X (2016) NGF increases VEGF expression and promotes cell proliferation via ERK1/2 and AKT signaling in Müller cells. Mol Vis 22:254-263.

Wells JM and Watt FM (2018) Diverse mechanisms for endogenous regeneration and repair in mammalian organs. Nature 557:322-328.

Werner S and Grose R (2003) Regulation of wound healing by growth factors and cytokines. Physiol Rev 83:835-870.

Westby MJ, Dumville JC, Soares MO, Stubbs N, and Norman G (2017) Dressings and topical agents for treating pressure ulcers. Cochrane Database Syst Rev 6: CD011947.

Yorek MA (2016) Alternatives to the streptozotocin-diabetic rodent. Int Rev Neurobiol 127:89-112.

Yu M, Bell RH, Ho MM, Leung G, Haegert A, Carr N, Shapiro J, and McElwee KJ (2012) Deficiency in nucleotide excision repair family gene activity, especially ERCC3, is associated with non-pigmented hair fiber growth. PLoS One 7:e34185 DOI: 10.1371/journal.pone.0034185

Yu X, Qi Y, Zhao T, Fang J, Liu X, Xu T, Yang Q, and Dai X (2019) NGF increases FGF2 expression and promotes endothelial cell migration and tube formation through PI3K/Akt and ERK/MAPK pathways in human chondrocytes. Osteoarthritis Cartilage 27:526-534 DOI: 10.1016/j.joca.2018.12.007.

Zigrino P, Brinckmann J, Niehoff A, Lu Y, Giebeler N, Eckes B, Kadler KE, and Mauch C (2016) Fibroblast-derived MMP-14 regulates collagen homeostasis in adult skin. J Invest Dermatol 136:1575-1583 DOI: 10.1016/j.jid.2016.03.036.

Address correspondence to: Dr. L. Calzà, CIRI-SDV, University of Bologna, Via Tolara di Sopra 41/E, 40064 Ozzano dell'Emilia (BO), Italy. E-mail: laura.calza@unibo.it 